\title{
Thermostable lipases from the extreme thermophilic anaerobic bacteria Thermoanaerobacter thermohydrosulfuricus SOL1 and Caldanaerobacter subterraneus subsp. tengcongensis
}

\author{
Marina Royter · M. Schmidt • C. Elend • \\ H. Höbenreich · T. Schäfer · U. T. Bornscheuer • \\ G. Antranikian
}

Received: 4 June 2009/Accepted: 18 June 2009/Published online: 5 July 2009

(C) Springer 2009

\begin{abstract}
Two novel genes encoding for heat and solvent stable lipases from strictly anaerobic extreme thermophilic bacteria Thermoanaerobacter thermohydrosulfuricus (LipTth) and Caldanaerobacter subterraneus subsp. tengcongensis (LipCst) were successfully cloned and expressed in E. coli. Recombinant proteins were purified to homogeneity by heat precipitation, hydrophobic interaction, and gel filtration chromatography. Unlike the enzymes from mesophile counterparts, enzymatic activity was measured at a broad temperature and $\mathrm{pH}$ range, between 40 and $90^{\circ} \mathrm{C}$ and between $\mathrm{pH} 6.5$ and 10; the half-life of the enzymes at $75^{\circ} \mathrm{C}$ and $\mathrm{pH} 8.0$ was $48 \mathrm{~h}$. Inhibition was observed with 4-(2-aminoethyl)-benzenesulfonyl fluoride hydrochloride and phenylmethylsulfonylfluorid indicating that serine and thiol groups play a role in the active site of the enzymes. Gene sequence comparisons indicated very low identity to already described lipases from mesophilic and psychrophilic microorganisms. By optimal cultivation of $E$. coli
\end{abstract}

Communicated by H. Santos.

M. Royter $(\bowtie) \cdot$ C. Elend · G. Antranikian

Institute of Technical Microbiology,

Hamburg University of Technology (TUHH),

Kasernenstrasse 12, 21073 Hamburg, Germany

e-mail: m.royter@tuhh.de

M. Schmidt · U. T. Bornscheuer

Department of Biotechnology and Enzyme Catalysis, Institute of Biochemistry, Greifswald University,

Felix-Hausdorff-Str. 4, 17487 Greifswald, Germany

H. Höbenreich

Max-Planck-Institut für Kohlenforschung,

Kaiser-Wilhelm-Platz 1, 45470 Mülheim, Germany

T. Schäfer

Novozymes A/S, Novo Alle, 2880 Bagsvaerd, Denmark
Tuner (DE3) cells in 2-1 bioreactors, a massive production of the recombinant lipases was achieved (53-2200 U/l) Unlike known lipases, the purified robust proteins are resistant against a large number of organic solvents (up to 99\%) and detergents, and show activity toward a broad range of substrates, including triacylglycerols, monoacylglycerols, esters of secondary alcohols, and $p$-nitrophenyl esters. Furthermore, the enzyme from $T$. thermohydrosulfuricus is suitable for the production of optically pure compounds since it is highly $S$-stereoselective toward esters of secondary alcohols. The observed $E$ values for but-3-yn-2-ol butyrate and but-3-yn-2-ol acetate of 21 and 16 , respectively, make these enzymes ideal candidates for kinetic resolution of synthetically useful compounds.

Keywords Thermophiles and thermophilic enzymes . Anaerobic bacteria - Genecloning and expression

\section{Introduction}

Lipases (triacylglycerol acylhydrolases, EC 3.1.1.3) are best defined as carboxylesterases that catalyze both the hydrolysis and synthesis of long-chain acylglycerols (Jaeger et al. 1999). True lipases can be defined as carboxylesterases that catalyze the hydrolysis and synthesis of relatively longchain acylglycerols with acyl chain lengths of $>10$ carbon atoms. Lipases share a similar active site consisting of three residues: a nucleophilic serine residue in a Gly-X-Ser-X-Gly motif, an acidic residue (aspartic acid or glutamic acid), and a histidine. These residues act cooperatively in the catalytic mechanism of ester hydrolysis. The enzymes also display a common $\alpha / \beta$ hydrolase fold (Ollis et al. 1992) which is also found in other hydrolases, such as haloalkane dehalogenase, acetylcholinesterase, dienelactone hydrolase, and serine 
carboxypeptidase. Based on comparisons of amino acid sequences and biological properties, prokaryote-derived lipases have been classified into eight different families (I-VIII) (Arpigny and Jaeger 1999).

Lipases are an important group of biotechnologically relevant enzymes, and they find applications in food, diary, detergent, and pharmaceutical industries. Most lipases, that are derived from mesophilic microorganisms, can act in a wide range of $\mathrm{pH}$ but are mostly unstable at temperatures above $70^{\circ} \mathrm{C}$. Bacterial lipases generally have temperature optima in the range of $30-65^{\circ} \mathrm{C}$. Recently, reports on diverse microbial, moderate thermoactive lipases from mesophiles have been published (Chung et al. 1991; Gilbert et al. 1991; Sugihara et al. 1991, 1992; Shabtai and Daya-Mishne 1992). Several lipases have been purified and characterized from moderate thermophilic isolates, mainly representatives of the genus Bacillus (Sugihara et al. 1991; Fakhreddine et al. 1998), such as the lipases from Bacillus thermoleovorans ID-1 (Lee et al. 1999), Bacillus thermocatenulatus (Schmidt-Dannert et al. 1994, 1996, 1997), Bacillus stearothermophilus (Kim et al. 1998, 2000; Sinchaikul et al. 2002), Bacillus sp. J33 (Nawani and Kaur 2000) or the lipase from Bacillus strain A30-1 (Wang et al. 1995). Several Pseudomonas (Sugihara et al. 1992; Lee and Rhee 1993; Ahn et al. 1999) and Lactobacillus (Lopes Mde et al. 2002) species have also been reported to produce moderate thermoactive lipases.

Microorganisms living at temperatures above $70^{\circ} \mathrm{C}$ (extreme thermophiles), however, are an interesting source of stable enzymes (extremozymes). They are in general superior to the traditional biocatalysts, because they produce proteins with unique properties and show reasonable activity even at $100^{\circ} \mathrm{C}$ and in the presence of organic solvents and detergents (Antranikian 2008). Little, however, is known on the lipolytic enzyme systems of extreme thermophiles, especially from strictly anaerobic bacteria. Their enzymes are expected to be a powerful tool in industrial biotransformation processes (Coolbear et al. 1992; Lasa and Berenguer 1993; Haki and Rakshit 2003).

The ability of Thermosyntropha lipolytica gen. nov., sp. nov., to utilize short- and long-chain fatty acids was described (Svetlitshnyi et al. 1996) and the cloning, purification, and characterization of a thermostable esterase from Thermoanaerobacter tengcongensis was reported (Zhang et al. 2003). To our knowledge, however, there are no reports on detailed characteristics of lipases from extreme thermophilic anaerobic bacteria.

In this work, we report on the properties of novel recombinant thermostable lipases from the extreme thermophilic anaerobic bacteria Thermoanaerobacter thermohydrosulfuricus and Caldanaerobacter subterraneus subsp. tengcongensis (Royter 2006).

\section{Materials and methods}

Bacterial strains and plasmids

The strain DSM 7021 Thermoanaerobacter thermohydrosulfuricus (basonym: Clostridium thermohydrosulfuricum) SOL1 was isolated from a Solar Lake and belongs to the genus Thermoanaerobacter (Klingeberg et al. 1990; Lee et al. 1993).

Caldanaerobacter subterraneus subsp. tengcongensis (basonym: Thermoanaerobacter tengcongensis) was obtained from German Collection of Microorganisms and Cell Cultures (DSMZ) number DSM 15242, Braunschweig, Germany (Fardeau et al. 2004). The genome of $C$. subterraneus subsp. tengcongensis has been sequenced (Bao et al. 2002) (GenBank AE008691). The extremely thermophilic anaerobic bacterium, designated strain MB4T, was isolated from a Chinese hot spring in Tengcong (Xue et al. 2001).

The Escherichia coli strains used in DNA manipulations were: TOP-10 [F- $m c r \mathrm{~A} \quad \Delta \quad$ (mrr-hsdRMS-mcrBC) p80lacZ $\Delta \mathrm{M} 15 \Delta$ lacX74 rec $\mathrm{A} 1$ deo $\mathrm{R}$ ara $\mathrm{D} 139 \Delta$ (araleu)7697 galU galK rpsL (StrR) end $\mathrm{A} 1$ nup G] (Invitrogen), NovaBlue [endAl hsdR17(rK12 - mK12 +) supE44 thi-1 recAl gyrA96 relA1 lac $\mathrm{F}^{\prime}[$ proA $+B+$ lacIqZ $\triangle M 15$ $:: \operatorname{Tn} 10(\mathrm{TcR})] \quad$ (Novagen) and $\operatorname{Tuner}^{\mathrm{TM}}(\mathrm{DE} 3)$ pLacI [F- ompT hsdSB(rB - mB -) gal dcm lacYl (DE3) pLacI (CamR)] (Novagen). E. coli TOP-10 was used in combination with the cloning vector pCR 2.1-TOPO (Invitrogen) suitable for blue/white assays. E. coli Tuner $^{\mathrm{TM}}(\mathrm{DE} 3)$ pLacI and NovaBlue were used in combination with vector pETBlue-1 (Novagen) containing the T7 promoter to clone and express the lipase gene.

\section{Media and culture conditions}

The basal medium for cultivation of T. thermohydrosulfuricus and $C$. subterraneus subsp. tengcongensis was prepared by the modified Hungate technique (Balch and Wolfe 1976). Medium for cultivation of the thermophilic anaerobic strains contained (per liter): $\mathrm{NaCl} 3.0 \mathrm{~g} ; \mathrm{KH}_{2} \mathrm{PO}_{4}$ $2.5 \mathrm{~g} ; \mathrm{NaH}_{2} \mathrm{PO}_{4} 0.8 \mathrm{~g} ; \mathrm{MgSO}_{4} \cdot 7 \mathrm{H}_{2} \mathrm{O}, 0.1 \mathrm{~g} ; \mathrm{CaCl}_{2} \cdot 2 \mathrm{H}_{2} \mathrm{O}$ $0.05 ; \mathrm{FeCl}_{3} \cdot 6 \mathrm{H}_{2} \mathrm{O} 0.01 \mathrm{~g} ;\left(\mathrm{NH}_{4}\right)_{2} \mathrm{SO}_{4} 1.5 \mathrm{~g} ; \mathrm{SrCl}_{2} \cdot 6 \mathrm{H}_{2} \mathrm{O}$ $0.03 \mathrm{~g} ; \mathrm{H}_{3} \mathrm{BO}_{3} 0.03 \mathrm{~g} ; \mathrm{Na}_{2} \mathrm{WO}_{4} 0.03 \mathrm{~g}$; yeast extract $1.5 \mathrm{~g}$; peptone $1.5 \mathrm{~g}$; trace element solution $(\times 10)$ [according to medium 141 (DSMZ 1998)] $1 \mathrm{ml}$; vitamin solution $(\times 10)$ (according to medium 141) $1 \mathrm{ml}$; resazurin $0.001 \mathrm{~g}$; $\mathrm{NaHCO}_{3} 1.0 \mathrm{~g}$; cysteine $0.3 \mathrm{~g}$; pH 7.2.

Prior to inoculation, $1 \mathrm{mg} \mathrm{Na} \mathrm{Na}_{2} \mathrm{~S} \cdot 9 \mathrm{H}_{2} \mathrm{O}$ was added to $20 \mathrm{ml}$ of medium and followed by the addition of $0.05 \mathrm{~g}$ $\mathrm{Na}_{2} \mathrm{~S}_{2} \mathrm{O}_{3}$.

For lipase production, the thermophilic anaerobic strains were cultivated on a rotary shaker $(160 \mathrm{rpm})$ for $32 \mathrm{~h}$ at 
$65^{\circ} \mathrm{C}$ in $50-\mathrm{ml}$ bottles under anaerobic conditions containing $20 \mathrm{ml}$ of the corresponding liquid medium. All $E$. coli strains were cultivated in Luria-Bertani medium [1\% (w/v) tryptone, $0.5 \%(w / v)$ yeast extract, $1 \%(w / v) ~ N a C l$ per liter of deionized water, $\mathrm{pH} 7.0]$ at $37^{\circ} \mathrm{C}$. Carbenicillin, when added, was used at a final concentration of $50 \mu \mathrm{g} / \mathrm{ml}$.

Recombinant DNA techniques

DNA manipulations were performed as described by Sambrook et al. (2001), unless otherwise stated. Restriction enzymes and other DNA-modifying enzymes were used according to the manufacturer's (Fermentas International Inc, Canada) recommendations. Genomic DNA was extracted from T. thermohydrosulfuricus and C. subterraneus subsp. tengcongensis using Qiagen column technology (Ausubel et al. 1987). E coli cells were transformed by "heat shock" method. Small-scale purification of plasmid DNA was performed using Qiagen column technology (Birnboim and Doly 1979; Birnboim 1983; Kraft et al. 1988). DNA fragments were isolated from agarose gels using a QIAquick gel extraction kit (Qiagen, USA), according to the manufacturer's instructions.

Sequencing and analysis of the genes

To determine the sequences of lipase gene of $T$. thermohydrosulfuricus, the PCR products and vectors with inserts were sequenced by SeqLab (Sequences Laboratories), Göttingen, Germany. The DNA and deduced amino acid sequences and chromatogram readouts were analyzed using the sequence analysis software VectorNTI and Chromas 1.45 (shareware).

Sequence and database similarity searches were done using the server at the National Center for Biotechnology Information, Bethesda, MD (http://www.ncbi.nlm.nih.gov). Analysis of the lipase genes was done with the Expasy Molecular Biology Server (http://www.expasy.org/tools). Sequence alignments were generated using ClustalW and Pairwise BLAST. Open reading frame analysis, translations, restriction mapping, polarity, hydrophobicity, and isoelectric point prediction were analyzed with the VectorNTI software (Infor-Max Inc., Oxford, UK).

Cloning and expression of the T. thermohydrosulfuricus and $C$. subterraneus subsp. tengcongensis lipase genes

The N-terminal sequence from $T$. thermohydrosulfuricus was compared with those of various known lipases from bacteria deposited in EMBL 29.0 and Swissprot 20.0 databases. On the basis of the best hits of the BLAST analysis, twelve various oligonucleotide primers were synthesized (Table 1a). Using these primers in all possible combinations, different internal fragments of the T. thermohydrosulfuricus DNA were amplified by PCR.

The PCR-products were sequenced and compared with other known hydrolase sequences. The DNA fragments identified as parts of hydrolase gene were completed using inverse-PCR techniques, in order to be able to express it actively in E. coli. The genomic DNA $(\sim 1.4 \mu \mathrm{g})$ was digested into small fragments with restriction enzymes BamHI and HindIII. The DNA-fragments were ligated and
Table 1 Oligonucleotides used for PCR-screening and inverse PCR

\begin{tabular}{llll}
\hline Number & Primer & Sequence $\left(5^{\prime}-3^{\prime}\right)$ & Function \\
\hline (a) PCR-screening & & \\
1F & LF/NT/CTT & CTTAAGGGGGATGTTGCATCTTC & Forward \\
2F & LF/NT/ATT & ATTAAGGGGGGTACTGCATCTG & Forward \\
3F & LF/OAH/CAT & CATGGGTTTACCGGAAATAAAGTGG & Forward \\
4F & F/CRI/TTC & TTCAGGCGAAAGCGACGGAG & Forward \\
5F & F/CRI/GGA & GGAACAGGTGAAAGTGATGGAGAATT & Forward \\
6F & F/CRI/GCG & GCGGTGAAAGTGATGGAGACTTT & Forward \\
7R & R/CRI/TCC & TCCGTCGCTTTCGCCTGAAC & Reverse \\
8R & R/CRI/AAA & AAATTCTCCATCACTTTCACCTGTTCC & Reverse \\
9R & R/CRI/TCT & TCTCCATCACTTTCACCGCTG & Reverse \\
10R & R/CRII/CAA & TCCTCCCATGCTGAGTCCCAA & Reverse \\
11R & R/CRII/AAG & TCCTCCCATGCTGAAGCCAAG & Reverse \\
12R & R/CTI/TTT & TTTTGTATGGTCCGCTCCTTCTAT & Reverse \\
(b) inverse PCR & & & \\
& 1F_Inv2Tth & GACATTTAGCAGTGAATTGGAAGATGC & Forward \\
& 2F_Inv2Tth & TTTGTGAAAGAGCCTACGACTGACC & Forward \\
& 3R_Inv2Tth & GCACTTTACCCTTAACATCATCAGGC & Reverse \\
& 4R_Inv2Tth & GACTCTACTTTATTGCCTGTAAAACCG & Reverse \\
\hline
\end{tabular}


the circular DNA-fragments were used as templates for amplification of lipase fragments using specific primers (Table 1b).

The program ContigExpress ${ }^{\mathrm{TM}}$ (Vector $\mathrm{NTI}^{\circledR}{ }^{\circledR}$, software package for Mac OS users developed by InforMax, Inc., North Bethesda, MD, USA) was used for analysis of the sequences and to complete the lipase gene.

AccepTor Vector Kit (Novagen) was used for IPTGinducible expression of lipase genes in E. coli under the control of the T7lac promoter in pETBlue-1 vector. Purified genomic DNAs from T. thermohydrosulfuricus and C. subterraneus subsp. tengcongensis were used as templates for amplification of complete lipase genes. The primers used for amplification of the T. thermohadrosulfuricus lipase gene were LipTth-for ( $5^{\prime}$-ATGCAAAAGG CT-GTTGAAATTAC- $3^{\prime}$ ) and LipTth-rev (5'-TTATCCC TTTAACAATTCCTTTTTG- $\left.3^{\prime}\right)$. The $C$. subterraneus subsp. tengcongensis lipase gene was amplified using constructed primers LipCs-for (5'-ATGCAGAAGGCTG TAGAGTTTAC-3') and LipCs-rev (5'-TTATCCCTT-T AATTCTCTTTCAAAG-3').

In the expression phase of the experiment, the clone containing lipase gene in reverse orientation was used as a negative control. $5 \mathrm{ml}$ of starter culture of the pETBlue-1 recombinant in an E. coli (DE3) pLacI expression host strain was grown in LB medium with $50 \mu \mathrm{g} \mathrm{ml}^{-1}$ of carbenicillin, $34 \mu \mathrm{g} \mathrm{ml}^{-1}$ of chloramphenicol and $1 \%$ glucose. $200 \mathrm{ml}$ medium inoculated with starter culture was incubated to an $\mathrm{OD}_{595}$ of 0.9. The cells were induced with $1 \mathrm{mM}$ isopropyl- $\beta$-D-thiogalactopyranoside (IPTG), and cultures were incubated with shaking at $37^{\circ} \mathrm{C}$ for $4 \mathrm{~h}$ for full induction.

E. coli clone containing $T$. thermohydrosulfuricus lipase gene was cultivated in a 2-1 fermentor (Bioengineering, Switzerland) with a working volume of 1.51 for $6 \mathrm{~h}$ at $37^{\circ} \mathrm{C}$, agitation at $1000 \mathrm{rpm}$ and aeration $\left(30 \mathrm{l} \mathrm{h}^{-1}\right)$.

\section{Lipase assay}

Positive recombinant clones isolated from triolein plates were cultivated in Luria-Bertani medium and assayed for lipase activity after $24 \mathrm{~h}$ incubation.

\section{Spectrophotometric assay with p-nitrophenyl palmitate as substrate}

Cleavage of $p$-nitrophenyl palmitate (Sigma, USA) was determined at $70^{\circ} \mathrm{C}$ in $0.025 \mathrm{M}$ Tris- $\mathrm{HCl}$ buffer, $\mathrm{pH} 8.0$, according to Winkler and Stuckmann (1979). A buffered $p$-nitrophenyl palmitate emulsion was sonicated for $2 \mathrm{~min}$ at room temperature before the kinetic measurement was started by the addition of the enzyme. A blank absorption at $410 \mathrm{~nm}$ was measured immediately after enzyme addition.
All values were determined in triplicates and corrected for autohydrolysis using an extinction coefficient of $\varepsilon=$ $12750 \mathrm{M}^{-1} \mathrm{~cm}^{-1}$. The activity toward other $p$-nitrophenyl esters was measured in the same manner, by using $1 \mathrm{mM}$ of each substrate. One unit $(1 \mathrm{U})$ of lipase activity is defined as the amount of enzyme needed to liberate $1 \mu \mathrm{mol}$ of $p$-nitrophenol per minute at the conditions described above.

\section{Spectrophotometric assay with olive oil as substrate}

In order to determine $\mathrm{pH}$ optimum of the enzymes a modified assay was used (Schmidt-Dannert et al. 1994). The hydrolytic activity of the lipase was measured by the spectrophotometric assay at $430 \mathrm{~nm}$ using the formation of copper soaps for the detection of free fatty acids. Enzyme reaction was carried out under shaking for $90 \mathrm{~min}$ at $70^{\circ} \mathrm{C}$. One unit $(1 \mathrm{U})$ of lipase activity is defined as the amount of enzyme needed to liberate $1 \mu \mathrm{mol}$ of free fatty acids per minute at the conditions described above.

Purification of recombinant lipases

After induction $E$. coli cells were harvested by centrifugation at $10000 \mathrm{~g}$ at $4^{\circ} \mathrm{C}$ for $30 \mathrm{~min}$. All purification procedures were performed at room temperature. After harvesting, the cells were washed twice with $50 \mathrm{mM}$ Tris$\mathrm{HCl}$ buffer $\mathrm{pH}$ 8.0, resuspended in $10 \mathrm{ml}$ of this buffer and stored at $-20^{\circ} \mathrm{C}$ for $1 \mathrm{~h}$. After thawing, lysozyme was added at a concentration of $100 \mathrm{mg} / \mathrm{ml}$ and Triton-X 100$0.1 \%$. The cells were incubated in the lysing reagents for $1 \mathrm{~h}$ on ice. DNAse was added to $100 \mathrm{mg} / \mathrm{ml}$ to one set and incubated at $37^{\circ} \mathrm{C}$ for $30 \mathrm{~min}$. After centrifugation the cell free extract was heated at $60^{\circ} \mathrm{C}$ for $30 \mathrm{~min}$. Proteins were precipitated and separated by centrifugation for $20 \mathrm{~min}$ at $10000 \mathrm{~g}$. $\mathrm{NaCl}$ was added to a concentration of $1 \mathrm{M}$, and $20 \mathrm{ml}$ of this supernatant were loaded on a $35-\mathrm{ml}$ phenyl sepharose high performance hydrophobic column $(20.0 \times 2.6 \mathrm{~cm}$, packed with $60 \mathrm{ml} 6 \mathrm{~F}$ high substituted resin) (Pharmacia, Sweden) preequilibrated with $50 \mathrm{mM}$ Tris- $\mathrm{HCl}$ buffer $\mathrm{pH} 8.0$ containing $1 \mathrm{M} \mathrm{NaCl}$. The protein was eluted with a linear reverse gradient from 1 to $0 \mathrm{M}$ $\mathrm{NaCl}$ at a flow rate of $1 \mathrm{ml} \mathrm{min}^{-1}$. Lipase containing fractions were pooled and dialyzed against 31 of standard buffer ( $\mathrm{pH}$ 8.0). The protein solutions were concentrated by ultrafiltration through a $10-\mathrm{kDa}$ cut-off membrane (Amicon). The samples were then fractionated on a HiLoad 16/ 60 Superdex 200 preparative grade column $(160 \times 16 \mathrm{~cm})$ (Pharmacia, Sweden) preequilibrated with standard buffer (pH 8.0) containing $1 \% \mathrm{NaCl}$ and $1 \%$ DMSO. The flow rate was adjusted to $1 \mathrm{ml} / \mathrm{min}$. Protein fractions with lipase activity were collected and dialyzed against standard buffer ( $\mathrm{pH}$ 8.0). The purified enzyme was stored at $+4^{\circ} \mathrm{C}$. Protein concentration was measured according the method of 
Bradford (1976). Bovine serum albumin was used as standard.

\section{Gel electrophoresis}

Protein samples were analyzed by sodium dodecyl sulfatepolyacrylamide gel electrophoresis (SDS-PAGE) using $12 \%$ polyacrylamide resolving gel and a $4 \%$ polyacrylamide stacking gel according to the method of Laemmli (1970) after the samples had been heated at $95^{\circ} \mathrm{C}$ for 5 min. The low molecular markers (Amersham, UK) used were: phophorylase b (97 kDa), albumin (66 kDa), ovalbumin $45 \mathrm{kDa})$, carbonic anhydrase $(830 \mathrm{kDa})$, trypsin inhibitor $20 \mathrm{kDa})$, a-lactalbumin (14.4 kDa). Proteins were visualized in the gels by staining with Coomassie brilliant blue R-250 (Sigma, USA). The zymogram staining with $\alpha$-naphthyl acetate for lipolytic activity was performed according to the method of Khalameyzer et al. (1999). When activity staining was performed, the sample applied to the gel was not boiled, and after electrophoresis SDS was removed by washing the gel with $0.5 \%$ Triton $\mathrm{X}-100$ for $20 \mathrm{~min}$ and with distilled water for $10 \mathrm{~min}$.

\section{Influence of $\mathrm{pH}$ and temperature}

The lipase activity was measured at a $\mathrm{pH}$ range from 4.0 to 12.0 using various buffers $(100 \mathrm{mM})$. All activity assays were performed at $70^{\circ} \mathrm{C}$. To study the $\mathrm{pH}$ stability of the enzyme, the lipase was incubated for 1 and $2 \mathrm{~h}$ at $30^{\circ} \mathrm{C}$ in the following buffers (100 mM): acetic acid/sodium acetate ( $\mathrm{pH} 4.0-5.5)$, potassium phosphate ( $\mathrm{pH}$ 5.0-8.0), Tris/ $\mathrm{HCl}(\mathrm{pH} 7.5-9.0)$ and glycine $/ \mathrm{NaCl} / \mathrm{NaOH}(\mathrm{pH}$ 9.0-13.0) without substrate. To determine the influence of the temperature on the enzymatic activity, samples were incubated at temperatures from 30 to $95^{\circ} \mathrm{C}$ for $15 \mathrm{~min}$. Thermostability was investigated after incubation of the samples at different temperatures from 70 to $90^{\circ} \mathrm{C}$ and $\mathrm{pH} 8.0$ at various time intervals.

\section{Effect of various compounds on lipase activity}

The effects of various substances (metal ions, inhibitors, organic solvents and surfactants) on lipase activity were examined using the spectrophotometric assay with $p$ nitrophenyl palmitate as substrate. The purified lipase was preincubated with various reagents in different concentrations at $30^{\circ} \mathrm{C}$ for $90 \mathrm{~min}$ without substrate, and residual lipase activity was measured using $p$-nitrophenyl palmitate.

\section{Substrate range}

The enzyme specificity was studied with $p$-nitrophenyl alkanoate esters of varying alkyl chain lengths from $\mathrm{C} 2$ to C18 compared with $p$-nitrophenyl palmitate as substrate.
The reaction was carried out at $70^{\circ} \mathrm{C}$ for $15 \mathrm{~min}$. The lipase specificity was tested toward the following triglycerides: triacetin $(\mathrm{C} 2: 0)$, tributyrin $(\mathrm{C} 4: 0)$, tricaproin $(\mathrm{C} 6: 0)$, tricaprylin $(\mathrm{C} 8: 0)$, tricaprin $(\mathrm{C} 10: 0)$, trilaurin $(\mathrm{C} 12: 0)$, trimyristin (C14:0), tripalmitin (C16:0), tristearin (C18:0), triolein (C18:1), compared with olive oil as substrate. Incubation was performed at $70^{\circ} \mathrm{C}$ for $24 \mathrm{~h}$.

Further substrates tested were: $p$-nitrophenyl esters of the following: benzoate, 2-(4-isobutylphenyl) propanoate (ibuprofen), 2-phenylpropanoate, 3-phenylbutanoate, cyclohexanoate, 2-(3-benzoylphenyl) propanoate (ketoprofen), 2-naphthoate, 1-naphthoate, adamantanoate and 2-(6-methoxynaphthalene-2-yl) propanoate (naproxen). The reaction was carried out at $70^{\circ} \mathrm{C}$ for $40 \mathrm{~min}$. The reaction mixture contained $950 \mu \mathrm{l}$ of buffer (100 mM Tris-HCl, pH 7.5), $50 \mu \mathrm{l}$ substrate $(5 \mathrm{mg} / \mathrm{ml}$ in DMSO) and $0.3 \mu \mathrm{g}$ of lipase. Activity was determined at $410 \mathrm{~nm}$ after $40 \mathrm{~min}$ of incubation at $75^{\circ} \mathrm{C}$.

Determination of catalytic activity and enantioselectivity by GC analysis

The enantioselectivity of the lipase from $T$. thermohydrosulfuricus toward racemic compounds was studied with 8 substrates. 6 of them were acetates, one a butyrate of a secondary alcohol and one an acetate of a tertiary (3-phenylbut-1-in-3-yl-acetate) alcohol. The general procedure for the preparation of the acetates 1-3 and 5-6 was already described (Musidlowska-Persson and Bornscheuer 2002; Schmidt et al. 2005). ( $R, S)$-racemic substrates were dissolved in sodium phosphate buffer $(50 \mathrm{mM}, \mathrm{pH} 7.5)$ giving $1 \mathrm{ml}$ of a $10 \mathrm{mM}$ solution. The solution was mixed by vortex for $2 \mathrm{~min}$. The hydrolysis was carried out in $1.5-\mathrm{ml}$ reaction vials in a thermomixer (Eppendorf) at $70^{\circ} \mathrm{C}$. $0.1 \mathrm{U}$ of the T. thermohydrosulfuricus lipase (based on the spectrophotometric $p$-NPP assay) was used for each reaction. The samples were taken after 2, 4, 16, 24, and $40 \mathrm{~h}$. Reactions were terminated by extraction with methylene chloride and the organic phases were dried over anhydrous sodium sulfate. For the detection of enantiomeric purity and conversion, gas chromatography was used (gas chromatograph, GC-14A, Shimadzu). The following conditions were used for the GC analyses: injection temperature $200^{\circ} \mathrm{C}$, detection temperature $200^{\circ} \mathrm{C}$, column (Heptakis-(2,6- $O$-methyl-3- $O$-pentyl)$\beta$-cyclodextrin, $25 \mathrm{~m} \times 0.25 \mathrm{~mm})$, carrier gas: $\mathrm{H}_{2}$, flame ionization detector (FID), temperature $110^{\circ} \mathrm{C}$ (isothermal) for 1-phenyl-1-ethyl acetate (1), 1-phenyl-2-pentyl acetate (2), 1-phenyl-2-butyl acetate (3), and 2-phenyl-but-1-in-3-yl acetate (4), column temperature $120^{\circ} \mathrm{C}$ (isothermal) for 1-phenyl-2-butyl acetate (5) and 1-phenyl-2-propyl acetate (6), column temperature $40^{\circ} \mathrm{C}$ (isothermal) for but-3-yn-2-ol acetate (7) and but-3-yn-2-ol butyrate (8) (Schmidt et al. 2006). The volume of the injected sample was $0.1 \mu \mathrm{l}$. With 
the help of the chromatogram the enantioselectivity $(E)$ and conversion $(c)$ were calculated according to Chen et al. (Schmidt et al. 2006).

Other esters (listed in Table 6) were incubated while the lipase from $T$. thermohydrosulfuricus in a mixture of $400 \mu \mathrm{l}$ buffer (125 mM Tris-HCl, $\mathrm{pH} 7.5$ ), $50 \mu$ l substrate $\left(10 \mathrm{mg} / \mathrm{ml}\right.$ in Acetonitrile) and $3 \mu \mathrm{g}$ enzyme at $30^{\circ} \mathrm{C}$. Sample were taken after $1 \mathrm{~h}, 24 \mathrm{~h}$ and 2 days $(500 \mu \mathrm{l}$ each), extracted with $300 \mu \mathrm{l}$ dichloromethane and analyzed by GC. The regioisomers of pentan-1,4-diyl diacetate-hydrolysis were resolved using a DB-Wax column [Hewlett-Packard, Palo Alto, CA, USA, 30 m (length), $0.32 \mathrm{~mm}$ (diameter), $0.25 \mu \mathrm{m}$ (film thickness)]. The relative activity was calculated on the basis of initial rates.

\section{Results}

Sequence analysis of lipases from

T. thermohydrosulfuricus and C. subterraneus subsp. tengcongensis

Sequences of the N-terminal amino acid (17 amino acids) of the lipase from $T$. thermohydrosulfuricus indicated high identity to the sequences of the hydrolase from C. subterraneus subsp. tengcongensis (NP 623397.1). Based on these identities, the hydrolase sequence $C$. subterraneus subsp. tengcongensis was compared to in NCBI BLAST database. Highest identity was obtained to hydrolases from
Clostridium acetobutylicum and Deinococcus radiodurans. 12 different oligonucleotide primers were synthesized and used to amplify the gene of $T$. thermohydrosulfuricus by PCR (Table 1a). The 142-bp fragment was amplified and had $84 \%$ identity to the nucleotide sequence of the hydrolase $\alpha / \beta$ superfamily from $C$. subterraneus subsp. tengcongensis (NP 623397.1). On the basis of this sequence, specific oligonucleotide primers were synthesized (Table 1b) to obtain the complete gene sequences of the lipase from $T$. thermohydrosulfuricus shown in Fig. 1. Nucleotide sequencing of this fragment revealed the presence of a unique open reading frame (ORF), starting at a putative ATG start codon and being 780-bp long. The lipase from $T$. thermohydrosulfuricus exhibits a low $G+C$ content $(36.15 \%)$. Preceeding the ATG start codon (6 bp upstream), a potential ribosome-binding site ShineDalgarno sequence ( $5^{\prime}$-GGAGG-3 $\left.{ }^{\prime}\right)$ was found. The deduced protein encoded by the lipase from $T$. thermohydrosulfuricus is composed of 259 residues, with a predicted molecular mass of $29161 \mathrm{Da}$ and a pI of $5.41 .35 \%$ of the amino acids are hydrophobic, $18 \%$ polar, $16 \%$ are acidic, and $13 \%$ are basic. The N-terminus of this protein contains no signal peptide (SignalP V3 program).

Cloning and expression of the T. thermohydrosulfuricus and $C$. subterraneus subsp. tengcongensis lipase genes

A 780-bp fragment containing the T. thermohydrosulfuricus lipase encoding gene (Fig. 1) and a 777-bp ORF
Fig. 1 Nucleotide sequence of the lipase from

T. thermohydrosulfuricus and open reading frame translation. Only the coding strand for Lipase 1 is shown. A putative ribosome-binding (ShineDalgarno) site is boxed. An active center containing the putative active-site serine is underlined
. . . ATGAAAGTATAGATA

TTGGTGCCTATGATACTTGT CTACATGGCTGTATTTATTG CTACGCAAACAGTAGTATCAGTA CTATAAAAAGAAATACAAAG CAGTACA ATGTAAATTCTCCTTTGTTG TGTAGCAAATTGACAGAAGA GGATGTAATAAAAGAAAGGG AAGTTAAATCTTGTGCTGTT TGGCAAACTT CAATTTTTGATAGATAAAAA ATCTGTCTATGTAGAAAAGT TTTCTTGACTGTAGTATAAT TGAATTATGAAATATTTGGAGGTGFTATTA $\begin{array}{ccccccc}\text { I } & \text { I } & \text { I } & \text { I } & \text { I } & \text { I } & \text { I } \\ \text { ATGCAAAAGGCTGTTGAAAT TACATATAACGGCAAAACTTTAAGAGGAATGATGCATTTG CCTGATGATGTTAAGGGTAAAGTGCCTATG }\end{array}$ $\begin{array}{lllllllllllllllllllllllllllllllllll}M & Q & K & A & V & E & I & T & Y & N & G & K & T & L & R & G & M & M & H & L & P & D & D & V & K & G & K & V & P & M & \end{array}$

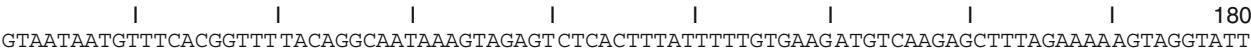
$\begin{array}{llllllllllllllllllllllllllllll}\mathrm{V} & I & M & \mathrm{~F} & \mathrm{H} & \mathrm{G} & \mathrm{F} & \mathrm{T} & \mathrm{G} & \mathrm{N} & \mathrm{K} & \mathrm{V} & \mathrm{E} & \mathrm{S} & \mathrm{H} & \mathrm{F} & \mathrm{I} & \mathrm{F} & \mathrm{V} & \mathrm{K} & \mathrm{M} & \mathrm{S} & \mathrm{R} & \mathrm{A} & \mathrm{L} & \mathrm{E} & \mathrm{K} & \mathrm{V} & \mathrm{G} & \mathrm{I}\end{array}$

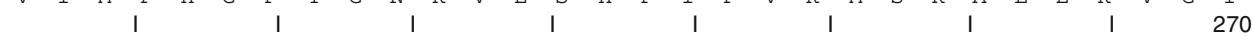
GGGAGTGTAAGGTTTGACTT TTATGGTTCTGGAGAAAGTGATGGGGACTTTAGTGAAATGACATTTAGCAGTGAATTGGAAGATGCAAGA

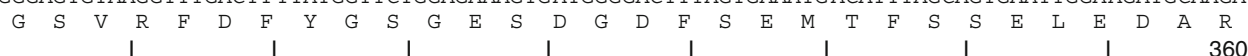
CAAATTTTAAAGTTTGTGAAAGAGCAACCTACGACTGACCCTGAGAGAATAGGACTACTT GGTTTGAGTATGGGAGGAGCTATTGCAGGG

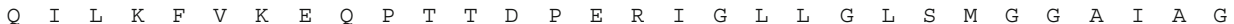

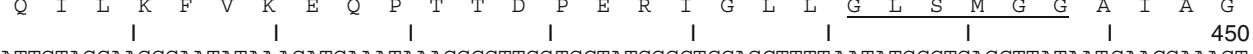
ATTGTAGCAAGGGAATATAAAGATGAAATAAAGGCGTTGG TGCTATGGGCTCCAGCTTTT AATATGCCTGAGCTTATAATGAACGAAAGT $\begin{array}{lllllllllllllllllllllllllllllll}I & V & A & R & E & Y & K & D & E & I & K & A & L & V & L & W & A & P & A & F & N & M & P & E & L & I & M & N & E & S\end{array}$

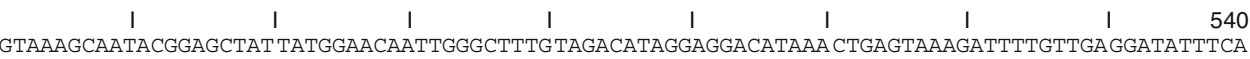
$\begin{array}{llllllllllllllllllllllllllllll}\mathrm{V} & K & Q & Y & G & A & I & M & E & Q & L & G & F & V & D & I & G & G & H & K & L & S & K & D & F & V & E & D & I & S\end{array}$

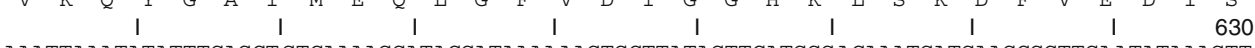
AAATTAAATATATTTGAGCT GTCAAAAGGATACGATAAAAAAGTGCTTATAGTTCATGGG ACAAATGATGAAGCGGTTGAATATAAAGTT $\begin{array}{lllllllllllllllllllllllllllllll}K & L & N & I & F & E & L & S & K & G & Y & D & K & K & V & L & I & V & H & G & T & N & D & E & A & V & E & Y & K & V\end{array}$ \begin{tabular}{lllllllllllllll}
\hline & I & I & I & I & I & I & I & I & I & 720
\end{tabular} TCTGATAGAATCTTAAAAGA GGTTTATGGGGATAACGCTA CAAGAGTGACAATCGAAAAT GCAGACCATACTTTTAAGAG TTTAGAATGG $\begin{array}{llllllllllllllllllllllllllllllll}S & D & R & I & L & K & E & V & Y & G & D & N & A & T & R & V & T & I & E & N & A & D & H & T & F & K & S & L & E & W\end{array}$

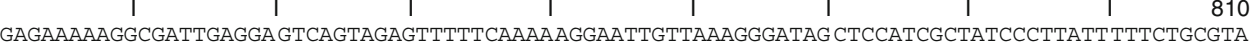
$\begin{array}{lllllllllllllllllllllllllll} & \mathrm{K} & \mathrm{K} & \mathrm{K} & \mathrm{A} & \mathrm{I} & \mathrm{E} & \mathrm{E} & \mathrm{S} & \mathrm{V} & \mathrm{E} & \mathrm{F} & \mathrm{F} & \mathrm{K} & \mathrm{K} & \mathrm{E} & \mathrm{L} & \mathrm{L} & \mathrm{K} & \mathrm{G} & \text { * }\end{array}$

AAGCTCAATTATTTTTATTA TTACTTCGACTGCTTTTTCCATTGCATATGTCGGTATAAA TTCATATTTACCGTGAAAATTATGCCCTCC

TGTGAATAAATTAgGTGTTGgAAgCCCCATATAgCTTAATCT. . . . 
(AE013133) encoding the C. subterraneus subsp. tengcongensis hydrolase (NP 623397.1) were amplified by PCR with specific primers (LipTth-for and LipTth-rev) and (LipCst-for and LipCst-rev), respectively (Royter 2006). Purified DNAs from $T$. thermohydrosulfuricus and $C$. subterraneus subsp. tengcongensis were used as template. T. thermohydrosulfuricus lipase encoding gene containing the ATG start codon was amplified without modification. A GTG start codon in the C. subterraneus subsp. tengcongensis hydrolase encoding gene, however, was replaced with the E. coli-specific ATG start codon at the $5^{\prime}$ end using special constructed primers. The purified PCR products with single $3^{\prime}$-dA overhangs were ligated into containing T7lac promoter linearized expression vector pETBlue-1 (Novagen, USA) designed for IPTG-inducible expression of target genes.

For initial expression studies in E. coli, plasmids pETBlue-1 containing complete lipase genes were constructed and transformed into the expression host strains Tuner $^{\mathrm{TM}}$ (DE3)pLacI. Expression was induced by the addition of Isopropyl- $\beta$-D-thiogalactopyranoside (IPTG) when the culture had attained late log phase $\left(\mathrm{OD}_{600}=0.9\right)$. The expression was optimized by testing various IPTG concentrations $(0.4,0.6,0.8,1.0,1.5$, and $2 \mathrm{mM}$ ). A halo around the colonies with lipase activity was observed on tributyrin plates. Expression levels were measured by SDS-PAGE (data not shown). Lipase activities were tested in cell-free supernatant and in cell lysate with $p$-nitrophenyl palmitate as substrate. The best expression (53-59 U/l) was achieved with $1 \mathrm{mM}$ IPTG for $4 \mathrm{~h}$. The enzyme level increased dramatically when cultivation was performed in a 2-1 fermentor at the optimal process parameters. The production of the recombinant lipase of $T$. thermohydrosulfuricus by $E$. coli Tuner (DE3) was increased 42-fold (from 53 to $2200 \mathrm{U} / \mathrm{l}$ ).
Purification of recombinant lipases

The recombinant lipases were purified by employing a three-step procedure: heat precipitation of cell free extract, hydrophobic interaction chromatography and gel filtration (Table 2). On phenyl sepharose column the enzymes were eluted at $\mathrm{NaCl}$ concentration between 0.90 and $0.95 \mathrm{M}$. The final gel filtration resulted in one peak of the active protein and in electrophoretically homogeneous preparations. The $T$. thermohydrosulfuricus lipase was purified 108.7-fold with $13 \%$ recovery and $C$. subterraneus subsp. tengcongensis lipase 93.6 -fold with $8.1 \%$ recovery. The specific activity of the recombinant enzymes ranged from 10.90 to $12.15 \mathrm{U} / \mathrm{mg}$. The purified enzymes showed on SDS-PAGE single bands with molecular weight of $34.2 \mathrm{kDa}$ for $T$. thermohydrosulfuricus and $32.1 \mathrm{kDa}$ for C. subterraneus subsp. tengcongensis (Fig. 2).

\section{Physicochemical properties}

The purified recombinant lipases exhibited maximum activity at a temperature of $75^{\circ} \mathrm{C}$ (Fig. 3) at $\mathrm{pH}$ 8.0. Both lipases were stable without significant loss of activity for 24-h incubation at temperatures up to $70^{\circ} \mathrm{C}$ (Fig. 4). After incubation at $85^{\circ} \mathrm{C}$ for $50 \mathrm{~min}, 90 \%$ of the lipase activity of T. thermohydrosulfuricus was measured.

The enzyme from C. subterraneus subsp. tengcongensis is less thermostable so that after 10 -min incubation at $85^{\circ} \mathrm{C}$, around $20 \%$ of residual activity was detected. The half-lives of the T. thermohydrosulfuricus lipase at $90^{\circ} \mathrm{C}$ is $50 \mathrm{~min}$ and of the C. subterraneus subsp. tengcongensis is $6 \mathrm{~min}$. The lipases were stable to freezing $\left(-20^{\circ} \mathrm{C}\right)$ and thawing. After first cycle of freezing and thawing, the enzymes showed $90 \%$ of residual activity and after second cycle the remaining activity was $85 \%$.

Table 2 Purification of the recombinant lipases from T. thermohydrosulfuricus and C. subterraneus subsp. tengcongensis

\begin{tabular}{|c|c|c|c|c|c|}
\hline & Total protein $(\mathrm{mg})$ & Total activity $^{\mathrm{a}}(\mathrm{U})$ & Specific activity $^{\mathrm{a}}(\mathrm{U} / \mathrm{mg})$ & Yield $(\%)$ & Purification (-fold) \\
\hline \multicolumn{6}{|c|}{ (a) Thermoanaerobacter thermohydrosulfuricus } \\
\hline Crude extract ${ }^{\mathrm{b}}$ & 233.60 & 26.1 & 0.11 & 100.0 & 1.0 \\
\hline Heat precipitation & 18.20 & 25.3 & 1.39 & 96.9 & 12.4 \\
\hline Phenyl sepharose & 2.30 & 12.6 & 5.48 & 48.3 & 49.0 \\
\hline Superdex 200 & 0.28 & 3.4 & 12.14 & 13.0 & 108.7 \\
\hline \multicolumn{6}{|c|}{ (b) Caldanaerobacter subterraneus } \\
\hline Crude extract ${ }^{\mathrm{b}}$ & 254.70 & 29.7 & 0.12 & 100.0 & 1.0 \\
\hline Heat precipitation & 15.40 & 19.2 & 1.25 & 64.6 & 10.7 \\
\hline Phenyl sepharose & 2.10 & 8.9 & 4.24 & 30.0 & 36.3 \\
\hline Superdex 200 & 0.22 & 2.4 & 10.91 & 8.1 & 93.6 \\
\hline
\end{tabular}

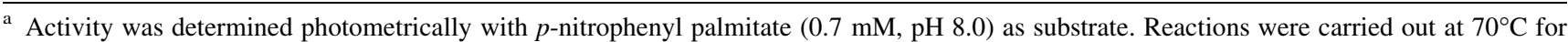
$10 \mathrm{~min}$

b $5 \mathrm{~g}$ of cells (E. coli) were resuspended in $10 \mathrm{ml} 50 \mathrm{mM}$ Tris- $\mathrm{HCl}$ buffer $\mathrm{pH} 8.0$ 


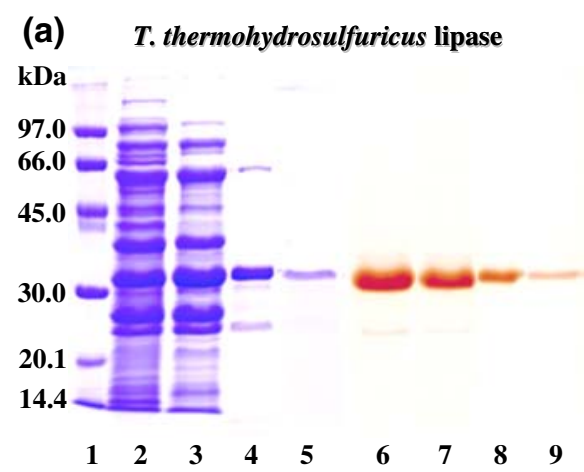

Fig. 2 SDS-PAGE analysis and zymogram of samples from purification steps of the recombinant lipases: a LipTth (T. thermohydrosulfuricus) and b LipCst (C. subterraneus subsp. tengcongensis). On the left panel, proteins were detected with coomassie blue $(0.1 \%)$.

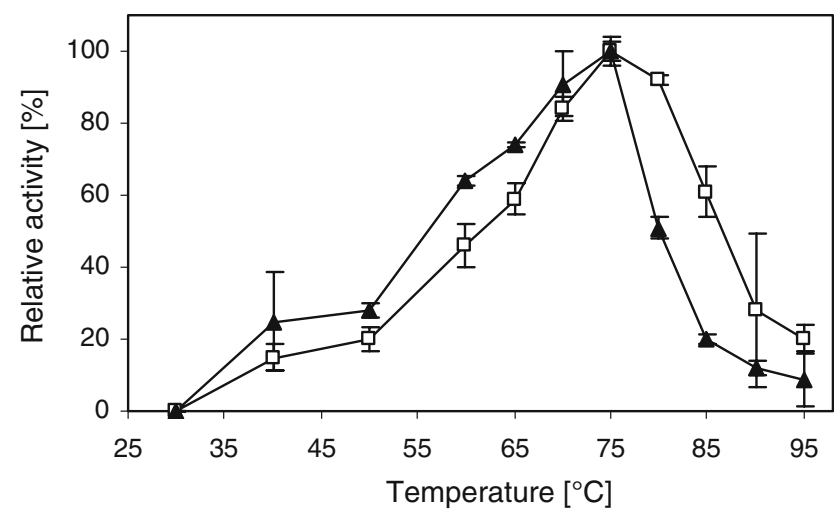

Fig. 3 Temperature profile of the recombinant lipases from $T$. thermohydrosulfuricus (filled triangle) and C. subterraneus subsp. tengcongensis (opened square). Enzyme activity of the recombinant lipases was determined over a temperature range from 30 to $95^{\circ} \mathrm{C}$. The substrate mixture $[0.7 \mathrm{mM} p$-nitrophenyl palmitate, $50 \mathrm{mM}$ Tris$\mathrm{HCl} \mathrm{pH} 8.0,0.1 \%(\mathrm{w} / \mathrm{v})$ gum Arabic] was prewarmed prior to addition of $6 \mathrm{mU}$ of the enzyme. Reactions were carried out for $10 \mathrm{~min}$. Reaction was terminated by placing the samples on ice and by addition of $\mathrm{Na}_{2} \mathrm{CO}_{3}$ to a final concentration of $10 \mathrm{mM}$. Samples were centrifuged for $2 \mathrm{~min}$ at $9400 \mathrm{~g}$. Photometrical measurements at wavelength $410 \mathrm{~nm}$ were done in triplicates and corrected for autohydrolysis of the substrate

The purified T. thermohydrosulfuricus lipase is active over a broad range of $\mathrm{pH}$ and showed maximum activity at $\mathrm{pH} 8.0$ and above $80 \%$ of activity at $\mathrm{pH}$ of 6.5 and 9.0 (Fig. 5). The C. subterraneus subsp. tengcongensis lipase showed an optimum activity at $\mathrm{pH} 7.0$ and above $60 \%$ of activity at $\mathrm{pH} 6.5$ and 9.0 (Fig. 5). The enzymes were completely stable in a pH range between 7.5 and 12 for $2 \mathrm{~h}$.

\section{Effects of different reagents}

The effect of various compounds is shown in Table 3. The following metal ions up to $10 \mathrm{mM}$ did not have any influence on the enzymes: $\mathrm{Na}^{+}, \mathrm{K}^{+}, \mathrm{Ca}^{2+}, \mathrm{Cu}^{2+}, \mathrm{Ag}^{+}, \mathrm{Mg}^{2+}$, $\mathrm{Mn}^{2+}, \mathrm{Sr}^{2+}, \mathrm{Rb}^{+}, \mathrm{Co}^{2+}, \mathrm{Ni}^{2+}$, and $\mathrm{Al}^{3+}$. In contrast, $\mathrm{Zn}^{2+}$,

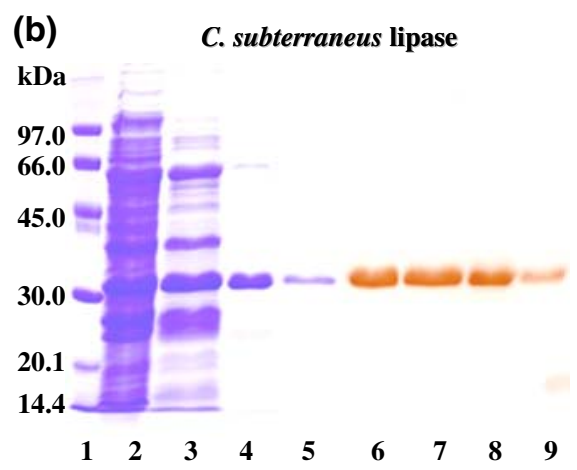

The right panel shows a zymogram with $\alpha$-naphthyl acetate. Lane 1 molecular markers $(2 \mu \mathrm{l})$; lanes 2 and 6 cell-free extract $(12 \mu \mathrm{g})$; lanes 3 and 7 heat precipitation pool $(10 \mu \mathrm{g})$; lanes 4 and 8 phenyl sepharose pool $(8 \mu \mathrm{g})$; lanes 5 and 9 superdex pool $(5 \mu \mathrm{g})$
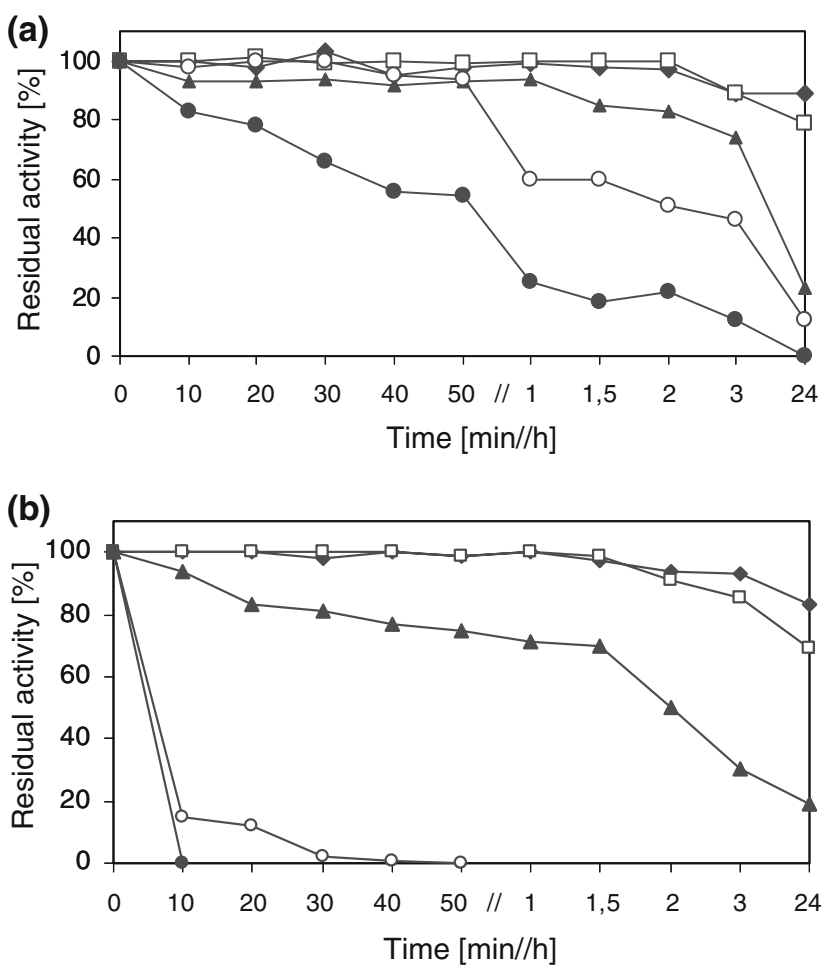

Fig. 4 Effect of temperature on stability of the recombinant lipases from $T$. thermohydrosulfuricus (a) and C. subterraneus subsp. tengcongensis (b). Thermostability of the recombinant lipases was determined by preincubation of the lipases at $\mathrm{pH} 8$ and different temperatures $70^{\circ} \mathrm{C}$ (filled diamond), $75^{\circ} \mathrm{C}$ (opened square), $80^{\circ} \mathrm{C}$ (filled triangle), $85^{\circ} \mathrm{C}$ (opened circle) and $90^{\circ} \mathrm{C}$ (filled circle) for various time intervals up to $24 \mathrm{~h}$. Standard assays with $0.7 \mathrm{mM}$ $p$-nitrophenyl palmitate were conducted at $\mathrm{pH} 8$ for $10 \mathrm{~min}$ at $70^{\circ} \mathrm{C}$ to determine the residual enzyme activity. Reaction was terminated by placing the samples on ice and by addition of $\mathrm{Na}_{2} \mathrm{CO}_{3}$ to a final concentration of $10 \mathrm{mM}$. Photometrical measurements at $410 \mathrm{~nm}$ were done in triplicates and corrected for autohydrolysis of the substrate

$\mathrm{Fe}^{3+}$, and $\mathrm{Cr}^{3+}$ ions were inhibitory. CHAPS (3-[(3-cholamidopropyl)dimethylammonio]-1-propanesulfonic acid) has a slight activating effect on both enzymes. A decrease in 


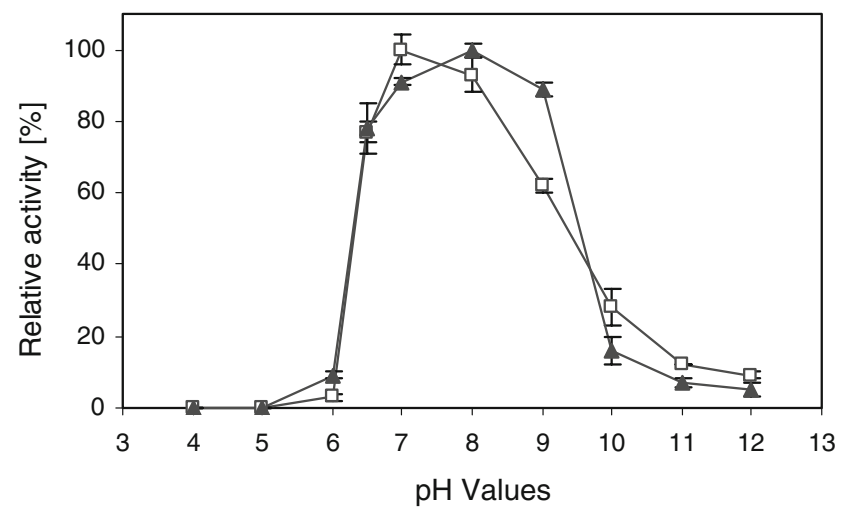

Fig. 5 Effect of $\mathrm{pH}$ on activity of the recombinant lipases from T. thermohydrosulfuricus (filled triangle) and C. subterraneus subsp. tengcongensis (opened square) was determined over a $\mathrm{pH}$ from 4 to 12 using $40 \mathrm{mM}$ universal buffer. The substrate mixture $[10 \mathrm{mM}$ tripalmitin, $50 \mathrm{mM}$ Tris- $\mathrm{HCl} \mathrm{pH}$ 8.0, 0.1\% (w/v) gum Arabic] was prewarmed prior to addition of $120 \mathrm{mU}$ of the enzyme. Reactions were carried out at $70^{\circ} \mathrm{C}$ for $1 \mathrm{~h}$. Measurements were done in triplicates

enzyme activity was observed after incubation with Tween20, Tween-80, Triton X-100 or SDS. The two lipases showed high activity in the presence of various solvents such as tert-butanol, acetonitrile, isopropanol, pyridine, and acetone up to a concentration of $99 \%$ (v/v). In contrast, DMSO (dimethyl sulfoxide), benzene, toluol, amylalcohol, and methanol at a concentration of $99 \%(\mathrm{v} / \mathrm{v})$ caused a significant reduction in enzyme activity (Table 3 ).

$\beta$-Mercaptoethanol, DTT (dithiotreitol), guanidine hydrochloride, Urea, pHMB ( $p$-hydroxymercuribenzoate), and iodo-acetate showed no effect. From the deduced amino acid sequences, it was suggested that these lipases harbor a catalytic triad consisting of Ser, His, and Asp, and accordingly they were inhibited by PMSF (phenylmethylsulfonyl fluoride) and pefablock (4-(2-aminoethyl)-benzenesulfonyl fluoride hydrochloride) (Table 3).

\section{Substrate specificity}

The recombinant lipases were active on a wide range of substrates. First, the specificity of the enzymes toward the length of different acyl chains of $p$-nitrophenyl esters was investigated (Table 4a). The enzymes were active on $p$-nitrophenyl esters of carboxylic acids of medium chain length (C6-C14). For both enzymes, $p$-nitrophenyl caprate (C10) was the most suitable substrate among the $p$-nitrophenyl esters examined. Both lipases exhibited very low levels of activity $(<10 \%)$ toward the short- (C2) and longchain (C18) substrates. The lipases from T. thermohydrosulfuricus and from C. subterraneus subsp. tengcongensis were able to hydrolyze further $p$-nitrophenyl ester substrates (Table 4b). Neither enzyme was able to hydrolyze $p$-nitrophenyl 2-naphthoate. Unlike the enzyme from C. subterraneus subsp. tengcongensis the lipase from
T. thermohydrosulfuricus was active toward 4-nitrophenol cyclohexanoate but not with $p$-nitrophenyl-1-naphthoate or $p$-nitrophenyl adamantanoate. Accordingly, the described lipases displayed different substrate spectra (Table 4b).

Both lipases showed high activities in the presence of the triacylglycerols with chain lengths of C6 and C8 (80 and $100 \%)$ and lower activity with C16 (30\%) (Table 4c).

\section{Enantioselectivity}

In order to determine the stereoselectivity of the thermoactive lipase from $T$. thermohydrosulfuricus, the substrates shown in Table 5 were investigated. With $(R, S)$-but-3-yn2-ol butyrate and $(R, S)$-but-3-yn-2-ol acetate, the lipase showd $(S)$-preference and catalyzed the synthesis of the building block (-)-but-3-yn-2-ol. After 2-h incubation, the enzyme exhibited the highest enantioselectivity and an $E$ value of 21 toward the butyrate was determined.

As shown in Table 5 the increase in conversion rate was accompanied with a decrease in the $E$ value. The $T$. thermohydrosulfuricus lipase showed higher preference to $(S)$-enantiomers; but over time, their ability to distinguish between the two enantiomers decreased. For two other substrates, 1-phenyl-2-propyl-acetate and 1-phenyl-1ethyl-acetate, the enantioselectivities of the enzyme where very low $(E \geq 1)$ but constant over time.

Furthermore, a broad range of esters was tested, and it was found that the lipase from $T$. thermohydrosulfuricus converted preferentially esters of secondary alcohols rather than esters of primary alcohols (Table 6).

\section{Discussion}

Microorganisms that thrive in extreme habitats especially at elevated temperatures $\left(70-100^{\circ} \mathrm{C}\right)$ are able to produce thermoactive enzymes that in general show high catalytic activity at the optimal growth conditions. Few moderate thermophilic strains $\left(50-60^{\circ} \mathrm{C}\right)$, especially representatives of the genus Bacillus, are able to produce extracellular enzymes, e.g., proteases that are even active at temperatures above their growth optimum (Schmidt-Dannert et al. 1994, 1997; Kambourova et al. 1996; Lee et al. 1999; Markossian et al. 2000; Nawani and Kaur 2000). Regarding lipases, however, there are few reports on the production of such enzymes by extreme thermophilic microorganisms $\left(70-80^{\circ} \mathrm{C}\right)$, especially strict anaerobes. The thermophilic bacterium Thermosyntropha lipolytica gen. nov., sp. nov., is able to utilize short- and long-chain fatty acids indicating its ability to produce lipase (Svetlitshnyi et al. 1996). The thermophilic bacterium $T$. tengcongensis produces an esterase, which is inactive toward olive oil and shows very low activity toward long chain $p$-NP esters (C16) (Zhang 
Table 3 Effects of various compounds on the lipase activity
Prior to the standard activity assay, the enzymes $(6 \mathrm{mU})$ were preincubated with various reagents at $30^{\circ} \mathrm{C}$ for $90 \mathrm{~min}$. Activity was determined with $p$-nitrophenyl palmitate $(0.7 \mathrm{mM}, \mathrm{pH} 8.0)$ as substrate. Reactions were carried out at $70^{\circ} \mathrm{C}$ for $10 \mathrm{~min}$. Enzyme activity determined in the absence of metal ions, detergents, inhibitors and denaturing agents was defined as $100 \%$ activity

\begin{tabular}{|c|c|c|c|}
\hline \multirow[t]{2}{*}{ Compounds } & \multirow[t]{2}{*}{ Concentration } & \multicolumn{2}{|c|}{ Relative activity (\%) on lipases from } \\
\hline & & T. thermohydrosulfuricus & $\begin{array}{l}\text { C. subterraneus subsp. } \\
\text { tengcongensis }\end{array}$ \\
\hline None & - & 100 & 100 \\
\hline $\mathrm{NaCl}$ & $10 \mathrm{mM}$ & 102 & 105 \\
\hline $\mathrm{KCl}$ & $10 \mathrm{mM}$ & 101 & 95 \\
\hline $\mathrm{CaCl}_{2}$ & $10 \mathrm{mM}$ & 95 & 94 \\
\hline $\mathrm{CuCl}_{2}$ & $10 \mathrm{mM}$ & 102 & 100 \\
\hline $\mathrm{AgNO}_{3}$ & $10 \mathrm{mM}$ & 98 & 99 \\
\hline $\mathrm{MgCl}_{2}$ & $10 \mathrm{mM}$ & 100 & 102 \\
\hline $\mathrm{MnCl}_{2}$ & $10 \mathrm{mM}$ & 88 & 103 \\
\hline $\mathrm{SrCl}_{2}$ & $10 \mathrm{mM}$ & 91 & 90 \\
\hline $\mathrm{RbCl}_{2}$ & $10 \mathrm{mM}$ & 101 & 102 \\
\hline $\mathrm{CoCl}_{2}$ & $10 \mathrm{mM}$ & 91 & 94 \\
\hline $\mathrm{NiCl}_{2}$ & $10 \mathrm{mM}$ & 84 & 96 \\
\hline $\mathrm{AlCl}_{3}$ & $10 \mathrm{mM}$ & 97 & 61 \\
\hline $\mathrm{ZnCl}_{2}$ & $10 \mathrm{mM}$ & 47 & 20 \\
\hline $\mathrm{FeCl}_{3}$ & $10 \mathrm{mM}$ & 50 & 71 \\
\hline $\mathrm{CrCl}_{3}$ & $10 \mathrm{mM}$ & 18 & 16 \\
\hline CHAPS & $10 \%(\mathrm{w} / \mathrm{v})$ & 129 & 111 \\
\hline Polyvinyl alcohol & $10 \%(\mathrm{w} / \mathrm{v})$ & 94 & 114 \\
\hline Tween-80 & $10 \%(\mathrm{v} / \mathrm{v})$ & 22 & 8 \\
\hline Tween-20 & $10 \%(\mathrm{v} / \mathrm{v})$ & 11 & 21 \\
\hline Triton X-100 & $10 \%(\mathrm{v} / \mathrm{v})$ & 11 & 12 \\
\hline SDS & $10 \%(\mathrm{w} / \mathrm{v})$ & 0 & 0 \\
\hline Tert-butanol & $99 \%(\mathrm{v} / \mathrm{v})$ & 113 & 118 \\
\hline Ethanol & $99 \%(\mathrm{v} / \mathrm{v})$ & 76 & 127 \\
\hline Acetonitrile & $99 \%(\mathrm{v} / \mathrm{v})$ & 110 & 100 \\
\hline Isopropanol & $99 \%(\mathrm{v} / \mathrm{v})$ & 96 & 111 \\
\hline Pyridine & $99 \%(\mathrm{v} / \mathrm{v})$ & 93 & 97 \\
\hline \multirow[t]{2}{*}{ DMSO } & $50 \%(\mathrm{v} / \mathrm{v})$ & 106 & 96 \\
\hline & $99 \%(\mathrm{v} / \mathrm{v})$ & 0 & 1 \\
\hline Acetone & $99 \%(\mathrm{v} / \mathrm{v})$ & 105 & 104 \\
\hline Dimethylformamide & $99 \%(\mathrm{v} / \mathrm{v})$ & 80 & 49 \\
\hline Methanol & $99 \%(\mathrm{v} / \mathrm{v})$ & 56 & 50 \\
\hline Hexadecane & $99 \%(\mathrm{v} / \mathrm{v})$ & 79 & 63 \\
\hline Heptane & $99 \%(\mathrm{v} / \mathrm{v})$ & 76 & 71 \\
\hline$n$-Hexane & $99 \%(\mathrm{v} / \mathrm{v})$ & 77 & 72 \\
\hline Isooctane & $99 \%(\mathrm{v} / \mathrm{v})$ & 68 & 54 \\
\hline Amylalcohol & $99 \%(\mathrm{v} / \mathrm{v})$ & 39 & 51 \\
\hline$n$-Decyl alcohol & $99 \%(\mathrm{v} / \mathrm{v})$ & 34 & 26 \\
\hline Toluol & $99 \%(\mathrm{v} / \mathrm{v})$ & 18 & 13 \\
\hline Benzene & $99 \%(\mathrm{v} / \mathrm{v})$ & 0 & 4 \\
\hline$\beta$-Mercaptoethanol & $10.0 \mathrm{mM}$ & 106 & 107 \\
\hline DTT & $10.0 \mathrm{mM}$ & 103 & 107 \\
\hline pHMB & $1.0 \mathrm{mM}$ & 104 & 106 \\
\hline Guanidine- $\mathrm{HCl}$ & $10.0 \mathrm{mM}$ & 105 & 100 \\
\hline Urea & $100.0 \mathrm{mM}$ & 102 & 116 \\
\hline 2-Iodoacetate & $10.0 \mathrm{mM}$ & 99 & 97 \\
\hline EDTA & $10.0 \%(\mathrm{w} / \mathrm{v})$ & 76 & 66 \\
\hline \multirow[t]{2}{*}{ PMSF } & $0.1 \mathrm{mM}$ & 21 & 6 \\
\hline & $1.0 \mathrm{mM}$ & 2 & 0 \\
\hline \multirow[t]{2}{*}{ Pefablock } & $0.1 \mathrm{mM}$ & 2 & 3 \\
\hline & $1.0 \mathrm{mM}$ & 0 & 0 \\
\hline
\end{tabular}


Table 4 Substrate specificity of the recombinant lipases

\begin{tabular}{|c|c|c|}
\hline \multirow[t]{2}{*}{ Substrate } & \multicolumn{2}{|c|}{ Relative activity (\%) on lipases from } \\
\hline & $\begin{array}{l}T . \\
\text { thermohydrosulfuricus }\end{array}$ & $\begin{array}{l}\text { C. subterraneus } \\
\text { subsp. } \\
\text { tengcongensis }\end{array}$ \\
\hline \multicolumn{3}{|l|}{ (a) ${ }^{\mathrm{a}} p$-Nitrophenyl esters } \\
\hline$p$-Nitrophenyl acetate $(\mathrm{C} 2: 0)$ & 9 & 8 \\
\hline$p$-Nitrophenyl butyrate $(\mathrm{C} 4: 0)$ & 57 & 60 \\
\hline$p$-Nitrophenyl caproate (C6:0) & 81 & 84 \\
\hline$p$-Nitrophenyl caprylate (C8:0) & 90 & 90 \\
\hline$p$-Nitrophenyl caprate $(\mathrm{C} 10: 0)$ & 100 & 100 \\
\hline$p$-Nitrophenyl laurate $(\mathrm{C} 12: 0)$ & 84 & 82 \\
\hline$p$-Nitrophenyl myristate (C14:0) & 68 & 39 \\
\hline$p$-Nitrophenyl palmitate (C16:0) & 32 & 30 \\
\hline$p$-Nitrophenyl stearate $(\mathrm{C} 18: 0)$ & 8 & 9 \\
\hline \multicolumn{3}{|l|}{ (b) ${ }^{\mathrm{b}} p$-Nitrophenyl ester substrates } \\
\hline$p$-Nitrophenyl benzoate & 10 & 31 \\
\hline$p$-Nitrophenyl 2-(4-isobutylphenyl) propanoate & 3 & 0 \\
\hline p-Nitrophenyl 2-phenylpropanoate & 28 & 100 \\
\hline$p$-Nitrophenyl 3-phenylbutanoate & 31 & 99 \\
\hline$p$-Nitrophenyl cyclohexanoate & 100 & 0 \\
\hline$p$-Nitrophenyl 2-(3-benzoylphenyl) propanoate & 9 & 20 \\
\hline$p$-Nitrophenyl-2-naphthoate & 0 & 0 \\
\hline$p$-Nitrophenyl-1-naphthoate & 0 & 22 \\
\hline$p$-Nitrophenyl adamantanoate & 5 & 40 \\
\hline $\begin{array}{l}p \text {-Nitrophenyl 2-(6-methoxynaphthalen-2-yl) } \\
\text { propanoate }\end{array}$ & 16 & 0 \\
\hline \multicolumn{3}{|l|}{ (c) $)^{c}$ Triacylglycerols } \\
\hline Triacetin $(\mathrm{C} 2: 0)$ & 5 & 2 \\
\hline Tributyrin $(\mathrm{C} 4: 0)$ & 10 & 7 \\
\hline Tricaproin (C6:0) & 74 & 34 \\
\hline Tricaprylin (C8:0) & 100 & 100 \\
\hline Tricaprin (C10:0) & 15 & 15 \\
\hline Trilaurin $(\mathrm{C} 12: 0)$ & 11 & 12 \\
\hline Trimyristin (C14:0) & 8 & 10 \\
\hline Tripalmitin (C16:0) & 22 & 29 \\
\hline Tristearin (C18:0) & 9 & 14 \\
\hline Triolein (C18:1) & 12 & 12 \\
\hline Olive oil & 10 & 12 \\
\hline
\end{tabular}

${ }^{a}$ Reactions were initiated by addition of $6 \mathrm{mU}$ lipase and performed with $1 \mathrm{mM}$ p-nitrophenyl esters (pH 8.0) as substrates for $10 \mathrm{~min}$ at $70^{\circ} \mathrm{C}$. The highest activity observed with $p$-nitrophenyl caprate was defined as $100 \%$

${ }^{\mathrm{b}}$ Reactions were initiated by addition of $6 \mathrm{mU}$ lipase and carried out with $0.25 \mathrm{mg} / \mathrm{ml}$ $p$-nitrophenyl esters (pH 7.5) as substrates for $40 \mathrm{~min}$ at $70^{\circ} \mathrm{C}$. The highest activity observed with $p$-nitrophenyl cyclohexanoate was set as $100 \%$

${ }^{c}$ Reactions were initiated by addition of $120 \mathrm{mU}$ lipase and performed with $10 \mathrm{mM}$ triacylglycerols $(\mathrm{pH} \mathrm{8.0)}$ as substrates for $24 \mathrm{~h}$ at $70^{\circ} \mathrm{C}$ The highest activity observed with tricaprylin was defined as $100 \%$
Psychrobacter immobilis (PIR accession number S57275). Therefore, it is speculative to make any predictions regarding structure-function relationships of enzymes from various groups. However, it was interesting to note that both the studied lipases lack signal peptides that are usually present in enzymes that are secreted by bacteria. It can be speculated that probably another mechanism for enzyme secretion is present in these extremophiles or the signal peptide could not be identified by SignalP V3 program.

Analysis of the deduced amino acid sequence of newly described lipases indicated that these enzymes belong to family $\mathrm{V}$ of lipolytic enzymes, described by Agripny and axella sp. TA144 (PIR accession number S14276) and $16 \%$ with the lipase 1 from the psychrophilic strain 
Table 5 Determination of the stereoselectivity of the lipase from T. thermohydrosulfuricus toward secondary and tertiary alcohols

\begin{tabular}{lllll}
\hline Substrate & \multicolumn{4}{l}{ Incubation time } \\
\cline { 2 - 5 } & $2 \mathrm{~h}$ & $4 \mathrm{~h}$ & $16 \mathrm{~h}$ & $24 \mathrm{~h}$ \\
& $C(\%)^{\mathrm{a}} /$ & $C(\%) /$ & $C(\%) /$ & $C(\%) /$ \\
& $E^{\mathrm{b}}$ & $E$ & $E$ & $E$ \\
\hline Butinolbutyrate & $41 / 21$ & $53 / 18$ & $67 / 16$ & $68 / 15$ \\
Butinolacetate & $27 / 10$ & $39 / 13$ & $50 / 16$ & $50 / 14$ \\
1-Phenyl-2-propyl-acetate & $5 / 1$ & $9 / 1$ & $27 / 1$ & $30 / 1$ \\
1-Phenyl-1-ethyl-acetate & $9 / 1$ & $12 / 1$ & $47 / 1$ & $52 / 2$ \\
1-Phenyl-3-butyl-acetate & $-{ }^{\mathrm{c}} /-$ & $-/-$ & $-/-$ & $-/-$ \\
1-Phenyl-2-pentyl-acetate & $-/-$ & $-/-$ & $-/-$ & $-/-$ \\
1-Phenyl-2-butyl-acetate & $-/-$ & $-/-$ & $-/-$ & $-/-$ \\
2-Phenyl-but-1-in-3-yl- & $-/-$ & $-/-$ & $-/-$ & $-/-$ \\
acetate & & & & \\
\hline
\end{tabular}

${ }^{\mathrm{a}} C$ conversion $(\%),{ }^{\mathrm{b}} E$ enantiomeric ratio, ${ }^{\mathrm{c}}$ No product

Table 6 Conversion of esters with different alcohol moieties by the lipase from T. thermohydrosulfuricus

\begin{tabular}{|c|c|c|}
\hline Substrate & $\begin{array}{l}\text { Relative } \\
\text { activity } \\
(\%)\end{array}$ & $E$ value \\
\hline Phenyl acetate & 100 & \\
\hline Octyl acetate ${ }^{\mathrm{a}}$ & 1.157 & \\
\hline $\begin{array}{l}(R, S)-2,3 \text {-glycerindibutylether } \\
\text { acetate }^{\mathrm{a}}\end{array}$ & 2.179 & 2.7 \\
\hline$(R, S)-$ IPG acetate ${ }^{\mathrm{a}}$ & 1.134 & 1.1 \\
\hline$(R, S)$-2-Phenyl-1-propyl acetate ${ }^{\mathrm{a}}$ & 2.761 & 1.25 \\
\hline$(R, S)-\beta$-Citronellyl acetate ${ }^{\mathrm{a}}$ & 0.627 & 1.6 \\
\hline$(R, S)$-Pentane-1,4-diyl diacetate ${ }^{\text {abd }}$ & 0.716 & \\
\hline$(R, S)$-Octane-2-yl acetate ${ }^{\mathrm{b}}$ & 0.455 & $>200$ \\
\hline$(R, S)$-Octane-3-yl acetate ${ }^{\mathrm{b}}$ & 0.657 & $>200$ \\
\hline$(R, S)$-1-Phenylethyl acetate ${ }^{\mathrm{b}}$ & 0.873 & $\begin{array}{l}35 \text { ( } R \text { - } \\
\quad \text { Enantiomer) }\end{array}$ \\
\hline$(R, S)$-1-Phenylpropyl acetate ${ }^{\mathrm{b}}$ & 0.313 & 23 \\
\hline$(R, S)$-1-Indanol acetate ${ }^{\mathrm{b}}$ & 3.731 & 5 \\
\hline$(R, S)$-1-Cyclohexylethyl acetate ${ }^{\mathrm{b}}$ & 0.224 & 110 \\
\hline$(R, S)-$-Cyclohexyl acetate ${ }^{\mathrm{b}}$ & 0.590 & $>200$ \\
\hline$(R, S)$-1-(2-Naphthyl)-ethyl acetate ${ }^{\mathrm{b}}$ & 0.276 & 5 \\
\hline $\begin{array}{l}(R, S) \text {-3,3-Dimethyl-2-butan-2-yl } \\
\text { acetate }^{\text {b }}\end{array}$ & 0.015 & \\
\hline tert-Butyl octanoate ${ }^{c}$ & 0 & \\
\hline$(R, S)$-3-methyl-3-Nonanol octanoate ${ }^{\mathrm{c}}$ & 0 & \\
\hline$(R, S)$-3-methyl-3-Nonanol acetate ${ }^{\mathrm{c}}$ & 0 & \\
\hline$(R, S)$-Linalyl acetate ${ }^{\mathrm{c}}$ & 0 & \\
\hline$(R, S)$-2-Phenyl-2-butanol octanoate ${ }^{\mathrm{c}}$ & 0 & \\
\hline
\end{tabular}

Reactions were initiated by addition of $120 \mathrm{mU}$ lipase and performed with $1 \mathrm{mg} / \mathrm{ml}$ substrate at $30^{\circ} \mathrm{C}$. Analysis of the reaction product was done by GC. The highest activity observed with phenyl acetate was set as $100 \%$

${ }^{\mathrm{a}}$ primary ester, ${ }^{\mathrm{b}}$ secondary ester, ${ }^{\mathrm{c}}$ tertiary ester, ${ }^{\mathrm{d}}$ pentane-1,4-diyl diacetate is bifunctional
Jaeger (1999). In spite of the low identity, the four conserved regions shown in Fig. 6 are present: the HGF block containing the hydrophobic stretch in front of the lid putative oxyanion hole, the SMGG block containing the putative active-site serine, the G(DK)D block containing the putative active-site aspartic acid, and the GH block with the putative active-site histidine. The enzymes grouped in family $\mathrm{V}$ so far originate from mesophilic bacteria (Pseudomonas oleovorans, Haemophilus influenzae, Acetobacter pasteurianus) as well as from coldadapted bacteria (Moraxella sp., Psy. immobilis) and from the thermoacidophilic archaeon Sulfolobus acidocaldarius (Arpigny and Jaeger 1999). Interestingly, the lid region of the thermostable described lipases contains no tryptophane (W) residue, which is usually located in close contact with the active-site serine (Woolley and Petersen 1994).

Comparison of the 3D structure of lipases from psychrophiles, mesophiles and thermophiles indicates that these enzymes have the same catalytic mechanism with a similar 3D architecture (Vieille and Zeikus 2001). Due to the high sensitivity of cysteine to oxidation at elevated temperatures, its content seems to be reduced in thermoactive enzymes. Both lipases have no cysteines.

The lipase from $T$. thermohydrosulfuricus shows also enantioselectivity in the kinetic resolution of various racemic esters of secondary and tertiary alcohols (Table 5). Several biotransformations using lipases are already performed on an industrial scale (Bornscheuer and Kazlauskas 1999; Bornscheuer et al. 2000), but novel enzymes with high selectivity in combination with high stability under process condition are still needed. The majority of compounds investigated so far are secondary alcohols, because most hydrolases show sufficient enantioselectivity toward these compounds (Theil 1997) and they are important chiral modules for organic synthesis (Bornscheuer and Kazlauskas 1999). Lipase LipTth shows moderate $S$-enantioselectivity toward $(R, S)$-but-3-yn-2-ol, which is an important building block (Lesot et al. 1997; Graner et al. 2001; Cappelli et al. 2002; Schmidt et al. 2006). Furthermore, the lipase from T. thermohydrosulfuricus is able to convert other industrially relevant substrates. Interestingly, the enzyme shows a high preference for esters of secondary alcohols and a high selectivity for ( $\mathrm{R}$ ) enantiomers of pharmaceutically important substrates as well as $C$. antarctica lipase B (CALB) (Orrenius et al. 1995), Alcaligenes QL (Naemura et al. 1996), C. rugosa and P. cepacia lipases (PCLs) (Kazlauskas et al. 1991). It is highly enantioselective for $(R, S)$-octan-2-yl acetate, $(R, S)$-octan-3-yl acetate and $(R, S)$-1-(2-naphthyl)ethyl acetate with $E$ value $>200$. The $E$ value for $(R, S)-1$ cyclohexylethyl acetate was also synthetically useful with $E=110$. The enzyme prefers $(R)$-enantiomers of chiral alcohols according to the Kazlauskas-rule (Lesot et al. 1997; Graner et al. 2001; Cappelli et al. 2002; Schmidt et al. 2006). 


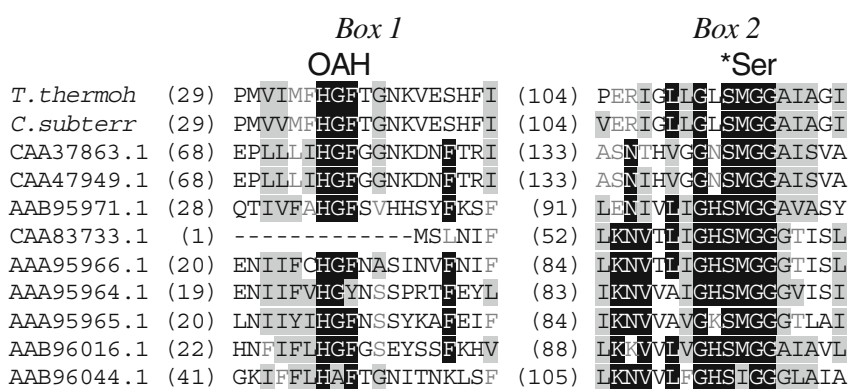

Fig. 6 Amino acid sequence blocks conserved in the deduced amino acid sequence of the T. thermohydrosulfuricus lipase and homologous lipases. Multiple amino acid sequence alignments of the T. thermohydrosulfuricus lipase, the C. subterraneus subsp. tengcongensis lipase and their homologs. The accession numbers of the aligned sequences are as follows: CAA37863.1, triacylglycerol lipase from Moraxella sp. (S14276, X53869); CAA47949.1, triacylglycerol lipase from Psychrobacter immobilis (S57275, X67712); AAB95971.1, triacylglycerol lipase 3 from Mycoplasma pneumoniae (strain ATCC 29342) (S73649); CAA83733.1, triacylglycerol lipase T from Mycoplasma capricolum (S77776, Z33059); AAA95966.1, triacylglycerol

The finding that the investigated lipases are active at elevated temperatures and high $\mathrm{pH}\left(90^{\circ} \mathrm{C}, \mathrm{pH} 11\right)$, in addition to their resistance against organic solvents (up to 99\%) makes these enzymes very attractive for biotransformation processes in water-free media (Jaeger et al. 1994; Kirk et al. 2002; Bommarius and Riebel 2004).

In summary, we were able to identify, clone and functionally express two novel lipases showing very high thermoactivity and stability. Moreover, both enzymes accept a very broad range of esters in hydrolysis and show good to excellent stereoselectivities in the kinetic resolution of a broad set of synthetically useful compounds important in organic synthesis.

Acknowledgment We acknowledge the financial support by the German Environmental Foundation (DBU), Osnabrück, Germany.

\section{References}

Ahn JH, Pan JG, Rhee JS (1999) Identification of the tliDEF ABC transporter specific for lipase in Pseudomonas fluorescens SIK W1. J Bacteriol 181(6):1847-1852

Antranikian G (2008) Industrial relevance of thermophiles and their enzymes. In: Robb F et al (eds) Thermophiles-biology and technology at high temperatures. CRC Press, Boca Raton, pp $113-160$

Arpigny JL, Jaeger KE (1999) Bacterial lipolytic enzymes: classification and properties. Biochem J 343(Pt 1):177-183

Ausubel FM, Brent R, Kingston RE, Moore DD, Seidman JD, Smith JA, Struhl K (1987) Current protocols in molecular biology. Wiley, New York

Balch WE, Wolfe RS (1976) New approach to the cultivation of methanogenic bacteria: 2-mercaptoethanesulfonic acid (HSCoM)-dependent growth of 8 in a pressureized atmosphere. Appl Environ Microbiol 32(6):781-791

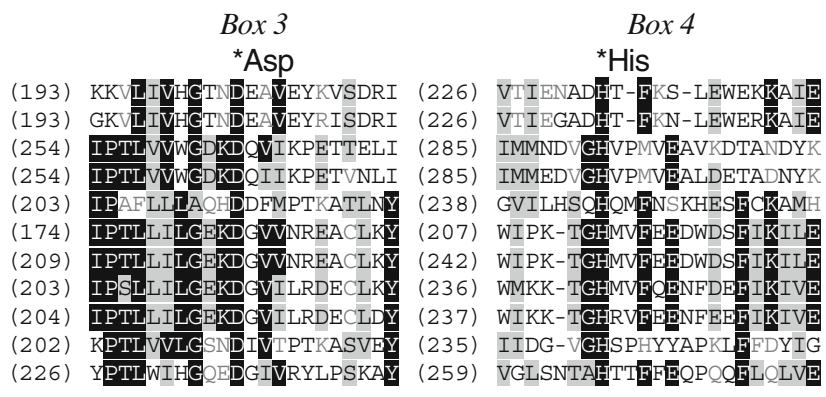

lipase 1 from Mycoplasma mycoides subsp. mycoides (JC4111); AAA95964.1, triacylglycerol lipase 1 from Mycoplasma mycoides subsp. mycoides (JC4109); AAA95965.1, triacylglycerol lipase 1 from Mycoplasma mycoides subsp. mycoides (JC4110); AAB96016.1, triacylglycerol lipase 2 from Mycoplasma pneumoniae (strain ATCC 29342) (S73694, AE000035); AAB96044.1, triacylglycerol lipase 3 from Mycoplasma pneumoniae (strain ATCC 29342) (S73722, AE000038). The accession numbers are indicated to the left of the amino acid sequences. Identical residues have a black background and similar residues have a gray background. *Amino acids forming a catalytic triad

Bao Q, Tian Y, Li W, Xu Z, Xuan Z, Hu S, Dong W, Yang J, Chen Y, Xue Y, Xu Y, Lai X, Huang L, Dong X, Ma Y, Ling L, Tan H, Chen R, Wang J, Yu J, Yang H (2002) A complete sequence of the T. tengcongensis genome. Genome Res 12(5):689-700

Birnboim HC (1983) A rapid alkaline extraction method for the isolation of plasmid DNA. Methods Enzymol 100:243-255

Birnboim HC, Doly J (1979) A rapid alkaline extraction procedure for screening recombinant plasmid DNA. Nucleic Acids Res 7(6):1513-1523

Bommarius AS, Riebel BR (2004) Biocatalysis. Wiley-VCH Verlag $\mathrm{GmbH} \& \mathrm{Co}$. KGaA, Weinheim

Bornscheuer UT, Kazlauskas RJ (1999) Hydrolases in organic synthesis. Regio- and stereoselective biotransformations. Wiley-VCH Verlag GmbH \& Co. KGaA, Weinheim

Bornscheuer UT, Rehm HJ, Reed G, Pühler A, Stadler PJW, Kelly DR (2000) Biotechnologies series. In: Indusrial Biotransformations. Wiley-VCH, Weinheim, vol 8b, pp 277-294

Bradford MM (1976) A rapid and sensitive method for the quantitation of microgram quantities of protein utilizing the principle of protein-dye binding. Anal Biochem 72:248-254

Cappelli C, Corni S, Mennucci B, Cammi R, Tomasi J (2002) Vibrational Circular Dichroism within the polarizable continuum model: a theoretical evidence of conformation effects and hydrogen bonding for (S)-(-)-3-butyn-2-ol in CCl4 solution. J Phys Chem A 106:12331-12339

Chung GH, Lee YP, Jeohn GH, Yoo OJ, Rhee JS (1991) Cloning and nucleotide sequence of thermostable lipase gene from Pseudomonas fluorescens SIK W1. Agric Biol Chem 55(9):2359-2365

Coolbear T, Daniel RM, Morgan HW (1992) The enzymes from extreme thermophiles: bacterial sources, thermostabilities and industrial relevance. Adv Biochem Eng Biotechnol 45:57-98

Fakhreddine L, Kademi A, Ait-Abdelkader N, Baratti J (1998) Microbial growth and lipolytic activities of moderate thermophilic bacterial strain. Biotechnol Lett 20(9):879-883

Fardeau M-L, Salinas MB, L'Haridon S, Jeanthon C, Verhé F, Cayol J-L, Patel BKC, Garcia J-L, Ollivier B (2004) Isolation from oil reservoirs of novel thermophilic anaerobes phylogenetically related to Thermoanaerobacter subterraneus: reassignment of T. subterraneus, Thermoanaerobacter yonseiensis, Thermoanaerobacter tengcongensis and Carboxydibrachium pacificum to 
Caldanaerobacter subterraneus gen. nov., sp. nov., comb. nov. as four novel subspecies. Int J Syst Evol Microbiol 54:467-474

Gilbert EJ, Cornish A, Jones CW (1991) Purification and properties of extracellular lipase from Pseudomonas aeruginosa EF2. J Gen Microbiol 137(Pt 9):2223-2229

Graner G, Hirota E, Iijima T, Kuchitsu K, Ramsay DA, Vogt J, Vogt N (2001) Molecules containing three or four carbon atoms. Springer, Heidelberg, p 25c

Haki GD, Rakshit SK (2003) Developments in industrially important thermostable enzymes: a review. Bioresour Technol 89(1):17-34

Jaeger KE, Ransac S, Dijkstra BW, Colson C, van Heuvel M, Misset O (1994) Bacterial lipases. FEMS Microbiol Rev 15(1):29-63

Jaeger KE, Dijkstra BW, Reetz MT (1999) Bacterial biocatalysts: molecular biology, three-dimensional structures, and biotechnological applications of lipases. Annu Rev Microbiol 53:315-351

Kambourova M, Emanuilova E, Dimitrov P (1996) Influence of culture conditions on thermostable lipase production by a thermophilic alkalitolerant strain of Bacillus sp. Folia Microbiol (Praha) 41(2):146-148

Kazlauskas RJ, Weissfloch ANE, Rappaport AT, Cuccia LA (1991) A rule to predict which enantiomer of a secondary alcohol reacts faster in reactions catalyzed by cholesterol esterase, lipase from Pseudomonas cepacia and lipase from Candida rugosa. J Org Chem 56:2656-2665

Khalameyzer V, Fischer I, Bornscheuer UT, Altenbuchner J (1999) Screening, nucleotide sequence, and biochemical characterization of an esterase from Pseudomonas fluorescens with high activity towards lactones. Appl Environ Microbiol 65(2):477482

Kim HK, Park SY, Lee JK, Oh TK (1998) Gene cloning and characterization of thermostable lipase from Bacillus stearothermophilus L1. Biosci Biotechnol Biochem 62(1):66-71

Kim MH, Kim HK, Lee JK, Park SY, Oh TK (2000) Thermostable lipase of Bacillus stearothermophilus: high-level production, purification, and calcium-dependent thermostability. Biosci Biotechnol Biochem 64(2):280-286

Kirk O, Borchert TV, Fuglsang CC (2002) Industrial enzyme applications. Curr Opin Biotechnol 13(4):345-351

Klingeberg M, Hippe H, Antranikian G (1990) Production of novel pullulanases at high concentrations by two newly isolated thermophilic Clostridia. FEMS Microbiol Lett 57(1-2):145152

Kraft R, Tardiff J, Krauter KS, Leinwand LA (1988) Using mini-prep plasmid DNA for sequencing double stranded templates with sequenase. Biotechniques 6(6):544-546, 549

Laemmli UK (1970) Cleavage of structural proteins during the assembly of the head of bacteriophage T4. Nature 227(259):680 685

Lasa I, Berenguer J (1993) Thermophilic enzymes and their biotechnological potential. Microbiologia 9(2):77-89

Lee SY, Rhee JS (1993) Production and partial purification of a lipase from Pseudomonas putida 3SK. Enzyme Microb Technol 15:617-623

Lee Y-E, Jain MK, Lee C, Lowe SE, Zeikus JG (1993) Taxonomic distinction of saccharolytic thermophilic anaerobes: description of Thermoanaerobacterium xylanolyticum gen. nov., sp. nov., and Thermoanaerobacterium saccharolyticum gen. nov., sp. nov.; reclassification of Thermoanaerobium brockii, Clostridium thermosulfurogenes, and Clostridium thermohydrosulfuricum E100-69 as Thermoanaerobacter brockii comb. nov., Thermoanaerobacterium thermosulfurigenes comb. nov., and Thermoanaerobacter thermohydrosulfuricus comb. nov., respectively; and transfer of Clostridium thermohydrosulfuricum 39E to Thermoanaerobacter ethanolicus. Int J Syst Bacteriol 43:41-51

Lee D, Koh Y, Kim K, Kim B, Choi H, Kim D, Suhartono MT, Pyun Y (1999) Isolation and characterization of a thermophilic lipase from Bacillus thermoleovorans ID-1. FEMS Microbiol Lett 179(2):393-400

Lesot P, Merlet D, Courtieu J, Emsley JW, Rantala TT, Jokisaari J (1997) Calculation of the molecular ordering parameters of $( \pm)$ 3-butyn-2-ol dissolved in an organic solution of poly(gammabenzyl-L-glutamate). J Phys Chem 101(31):5719-5724

Lopes Mde F, Leitao AL, Regalla M, Marques JJ, Carrondo MJ, Crespo MT (2002) Characterization of a highly thermostable extracellular lipase from Lactobacillus plantarum. Int J Food Microbiol 76(1-2):107-115

Markossian S, Becker P, Markl H, Antranikian G (2000) Isolation and characterization of lipid-degrading Bacillus thermoleovorans IHI-91 from an icelandic hot spring. Extremophiles 4(6):365371

Musidlowska-Persson A, Bornscheuer UT (2002) Substrate specificity of the y-isoenzyme of recombinant pig liver esterase towards acetates of secondary alcohols. J Mol Catal 19-20:129-133

Naemura K, Murata M, Tanaka R, Yano M, Hirose K, Tobe Y (1996) Enantioselective acylation of alcohols catalyzed by lipase QL from Alcaligenes sp.: a predictive active site model for lipase QL to identify the faster reacting enantiomer of an alcohol in this acylation. Tetrahedron Asymmetry 7:1581-1584

Nawani N, Kaur J (2000) Purification, characterization and thermostability of lipase from a thermophilic Bacillus sp. J33. Mol Cell Biochem 206(1-2):91-96

Ollis DL, Cheah E, Cygler M, Dijkstra B, Frolow F, Franken SM, Harel M, Remington SJ, Silman I, Schrag J (1992) The alpha/ beta hydrolase fold. Protein Eng 5(3):197-211

Orrenius C, Norin T, Hult K, Carrea G (1995) Lipase as chiral catalysts. Tetrahedron Asymmetry 6:3023-3030

Royter M (2006) Cloning and characterization of thermostable lipases from thermophilic anaerobic bacteria. PhD thesis, Hamburg, Germany

Sambrook J, Frisch EF, Maniatis T (2001) Molecular cloning: a laboratory manual, 3rd edn. Cold Spring Harbor Laboratory, Cold Spring Harbor

Schmidt M, Barbayianni E, Fotakopoulou I, Hohne M, ConstantinouKokotou V, Bornscheuer UT, Kokotos G (2005) Enzymatic removal of carboxyl protecting groups. 1. Cleavage of the tertbutyl moiety. J Org Chem 70(9):3737-3740

Schmidt M, Hasenpusch D, Kahler M, Kirchner U, Wiggenhorn K, Langel W, Bornscheuer UT (2006) Directed evolution of an esterase from Pseudomonas fluorescens yields a mutant with excellent enantioselectivity and activity for the kinetic resolution of a chiral building block. Chembiochemistry 7(5):805-809

Schmidt-Dannert C, Sztajer H, Stocklein W, Menge U, Schmid RD (1994) Screening, purification and properties of a thermophilic lipase from Bacillus thermocatenulatus. Biochim Biophys Acta 1214(1):43-53

Schmidt-Dannert C, Rua ML, Atomi H, Schmid RD (1996) Thermoalkalophilic lipase of Bacillus thermocatenulatus. I. Molecular cloning, nucleotide sequence, purification and some properties. Biochim Biophys Acta 1301(1-2):105-114

Schmidt-Dannert C, Rua ML, Schmid RD (1997) Two novel lipases from thermophile Bacillus thermocatenulatus: screening, purification, cloning, overexpression, and properties. Methods Enzymol 284:194-220

Shabtai Y, Daya-Mishne N (1992) Production, purification, and properties of a lipase from a bacterium (Pseudomonas aeruginosa YS-7) capable of growing in water-restricted environments. Appl Environ Microbiol 58(1):174-180

Sinchaikul S, Tyndall JD, Fothergill-Gilmore LA, Taylor P, Phutrakul S, Chen ST, Walkinshaw MD (2002) Expression, purification, crystallization and preliminary crystallographic analysis of a thermostable lipase from Bacillus stearothermophilus P1. Acta Crystallogr D Biol Crystallogr 58(Pt 1):182-185 
Sugihara A, Tani T, Tominaga Y (1991) Purification and characterization of a novel thermostable lipase from Bacillus sp. J Biochem (Tokyo) 109(2):211-216

Sugihara A, Ueshima M, Shimada Y, Tsunasawa S, Tominaga Y (1992) Purification and characterization of a novel thermostable lipase from Pseudomonas cepacia. J Biochem (Tokyo) 112(5):598-603

Svetlitshnyi V, Rainey F, Wiegel J (1996) Thermosyntropha lipolytica gen. nov., sp. nov., a lipolytic, anaerobic, alkalitolerant, thermophilic bacterium utilizing short- and long-chain fatty acids in syntrophic coculture with a methanogenic archaeum. Int J Syst Bacteriol 46(4):1131-1137

Theil F (1997) Enzymes in the organic synthesis. Spektrum Akademischer Verlag Heidelberg, Berlin, Oxford

Vieille C, Zeikus GJ (2001) Hyperthermophilic enzymes: sources, uses, and molecular mechanisms for thermostability. Microbiol Mol Biol Rev 65(1):1-43
Wang Y, Srivastava KC, Shen G-J, Wang HY (1995) Thermostable alkaline lipase from a newly isolated thermophilic Bacilus, strain A30-1 (ATCC 53841). J Ferment Bioeng 79(5):433-438

Winkler UK, Stuckmann M (1979) Glycogen, hyaluronate, and some other polysaccharides greatly enhance the formation of exolipase by Serratia marcescens. J Bacteriol 138(3):663-670

Woolley P, Petersen SB (1994) Lipases - their structure, biochemistry and application. Cambridge University Press, Cambridge

Xue Y, Xu Y, Liu Y, Ma Y, Zhou P (2001) Thermoanaerobacter tengcongensis sp. nov., a novel anaerobic, saccharolytic, thermophilic bacterium isolated from a hot spring in Tengcong, China. Int J Syst Evol Microbiol 51(Pt 4):1335-1341

Zhang J, Liu J, Zhou J, Ren Y, Dai X, Xiang H (2003) Thermostable esterase from Thermoanaerobacter tengcongensis: high-level expression, purification and characterization. Biotechnol Lett 25(17):1463-1467 